\title{
Failure Mechanisms in High Chrome Oxide Gasifier Refractories
}

\begin{abstract}
JAMES P. BENNETT and KYEI-SING KWONG
Gasification is a high-temperature, high-pressure chemical process used to convert a carbon feedstock into $\mathrm{CO}$ and $\mathrm{H}_{2}$ (syngas) for use in power generation and the production of chemicals. It is also a leading candidate as a source of hydrogen in a hydrogen economy and is one of several technologies expected to see increased use in advanced fossil fuel power systems in the future. Gasification is being evaluated because of its high efficiency, its ability to capture $\mathrm{CO}_{2}$ for sequestration or reuse in other applications, and its potential for carbon feedstock fuel flexibility. At the heart of the gasification process is a gasifier, a high pressure chemical reaction vessel used to contain the interactions between carbon and water in a shortage of oxygen, producing syngas. The gasifier is lined with high chrome oxide materials to protect the containment vessel. Gasifiers are complex systems, and failure of the refractories used to line them was identified by industry as a limitation to their reliability and availability and to their increased use. NETL researchers have examined spent high- $\mathrm{Cr}_{2} \mathrm{O}_{3}$ (over 90 pct $\mathrm{Cr}_{2} \mathrm{O}_{3}$ ) refractories from numerous gasifiers to determine in-service failure mechanisms. This analysis revealed that premature failure of the high chrome oxide refractories was related to ash in the carbon feedstock, which liquefies during gasification and interacts with the refractories, leading to wear by chemical dissolution or spalling (structural and chemical). A discussion of this postmortem wear of spent refractory materials and of thermodynamic modeling used to explain microstructural changes leading to wear are explained in this article. This information will serve the basis to develop improved performance refractory materials.
\end{abstract}

DOI: $10.1007 / \mathrm{s} 11661-011-0635-\mathrm{x}$

(C) The Minerals, Metals \& Materials Society and ASM International (outside the USA) 2011

\section{INTRODUCTION}

\section{A. Gasification}

GASIFICATION as a modern high-temperature, high-pressure industrial process was first used by the oil industry in the 1950s to process low-value petroleum and by-products from petroleum refining into higher value products. Since that time, gasification has expanded to other uses, including processing low-cost carbon materials for power generation and producing $\mathrm{CO}$ and $\mathrm{H}_{2}$ feedstock for use by the chemical industry (for applications from fertilizer to Fischer-Tropsch liquids), and is considered a leading candidate to produce $\mathrm{H}_{2}$ for a hydrogen-based economy. It is one of several technologies expected to see increased use in the future. Gasification is being evaluated, in part, because of its high efficiency, ability to capture $\mathrm{CO}_{2}$ for sequestration or reuse in other applications, and fuel flexibility.

As a process, gasification converts a carbon feedstock (typically methane, coal, or by-products from petroleum processing such as petcoke) into $\mathrm{CO}$ and $\mathrm{H}_{2}$ (called synthesis gas or syngas). The process of gasification

JAMES P. BENNETT and KYEI-SING KWONG, Ceramic Engineers, are with the National Energy Technology LaboratoryUSDOE, Albany, OR 97321. Contact e-mail: james.bennett@netl.doe.gov Manuscript submitted April 9, 2010.

Article published online March 3, 2011 occurs in a facility similar to the general flow sheet shown in Figure 1, with major downstream processing and applications or proposed applications for the syngas product shown. Gasification can occur using any of a number of gasifier designs, including dry ash gasifiers such as the Sasol-Lurgi* and Foster Wheeler designs

\footnotetext{
*Disclaimer: The use of commercial products and brand names does not imply endorsement by the DOE.
}

(slag typically does not fuse due to the low temperature of operation), water-cooled entrained bed slagging gasifiers such as the Shell and Siemens designs (gasification occurs at temperatures that create a molten slag from ash which is contained by a water-cooled refractory liner), and the air-cooled entrained-bed slagging gasifiers that include the ConocoPhillips and General Electric designs (these gasifiers operate at temperatures where ash liquefies into molten slag that flows down an air-cooled refractory liner surface). Each gasifier design has advantages and disadvantages that determine the amount and type of carbon feedstock it can process and the syngas composition produced.

Gasifiers are used to contain the severe service reaction between carbon feedstock (typically coal, petroleum coke, or biomass), water (or steam), and oxygen in a reducing environment (shortage of oxygen, with the oxygen partial pressure typically between $10^{-7}$ and $10^{-9} \mathrm{~atm}$ ), producing a primary product of $\mathrm{CO}$ and 


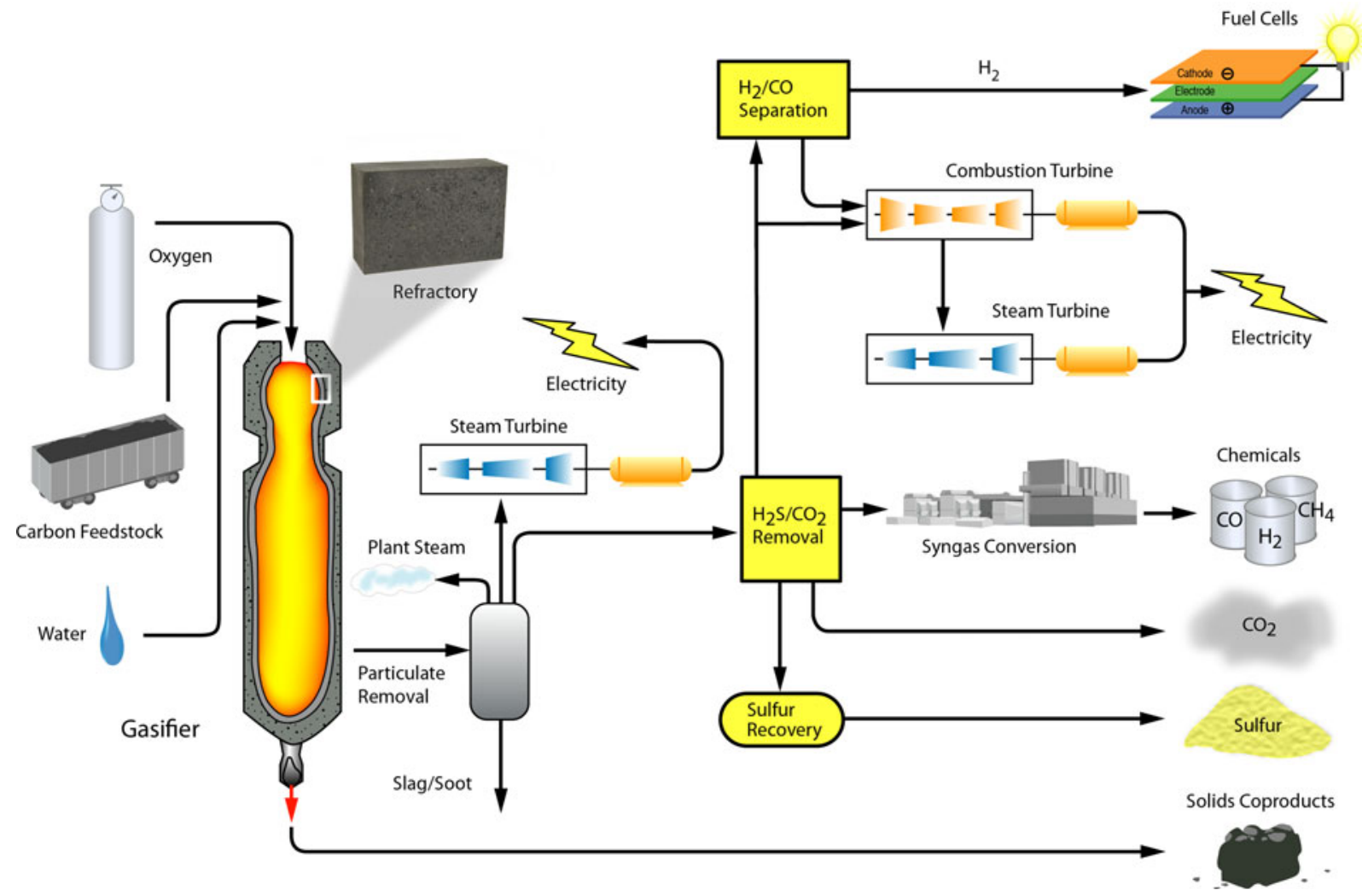

Fig. 1-Schematic of the overall gasification process.

$\mathrm{H}_{2}$ from the feedstock materials. The air-cooled slagging gasifiers currently used by industry (shown in Figure 1) are high-temperature, high-pressure reaction chambers, typically operating between $1598 \mathrm{~K}$ and $1848 \mathrm{~K}$ $\left(1325^{\circ} \mathrm{C}\right.$ and $\left.1575^{\circ} \mathrm{C}\right)$ and at pressures between 2.07 and $6.90 \mathrm{MPa}$. A number of by-products occur during gasification, with the overall process reaction shown as follows:

$$
\begin{aligned}
\mathrm{C}+ & \left.\mathrm{H}_{2} \mathrm{O} \text { (gas) }+\mathrm{O}_{2} \text { ( shortage }\right) \\
\rightarrow & \mathrm{CO}+\mathrm{H}_{2}+\mathrm{CO}_{2}+\text { minority gases } \\
& + \text { by-products }+ \text { heat }
\end{aligned}
$$

It should be noted that minority gases include $\mathrm{H}_{2} \mathrm{~S}$ $\mathrm{CH}_{4}, \mathrm{NH}_{3}, \mathrm{HCN}$, and $\mathrm{N}_{2}$, and $\mathrm{Ar}$ by-products include excess $\mathrm{C}$, sulfur, and mineral impurities in the carbon feedstock that become ash or slag.

The type, quantity, and amount of any minority gas or impurity are determined by the composition of the gasifier feedstock, the gasification temperature, or by other gasification conditions such as the $\mathrm{O}_{2}$ content. For most syngas applications, gas impurities are removed at the gasification site. This is accomplished using a variety of chemical processing techniques downstream from the gasifier, as shown in Figure 1. Because of the reducing environment of gasification, excess carbon from the feedstock becomes a by-product of the process, which can be recovered for reuse in the gasifier. Ideally, the amount of excess carbon should be small, about $1.0 \mathrm{wt}$ pct, ${ }^{[1]}$ but is dependent upon variables such as the gasifier type, carbon feedstock, and the $\mathrm{C} / \mathrm{O}_{2}$ ratio.
In the reducing environment of gasification, between 20 and 30 pct of the $\mathrm{O}_{2}$ required for complete combustion of the $\mathrm{C}$ and $\mathrm{H}_{2}$ in the carbon feedstock ${ }^{[2]}$ is supplied. Overall, gasification is considered a noncatalytic process that involves a number of endothermic and exothermic reactions, with the overall process being exothermic, ${ }^{[3]}$ as indicated in the preceding equation.

At the high-temperature and reducing environment of gasification, organic matter in the carbon feedstock is broken down, while inorganic materials (impurities) remain as discrete particles (ash) that can fuse, coalesce, and form slag, depending on the gasification temperature. When the ash becomes molten and coalesces as slag, it can flow down the sidewalls of the gasification chamber as liquid or leave the gasifier as individual airborne particles. Molten ash particles that contact and become attached to the gasifier sidewall that are not yet fluid enough to move under the influence of gravity (because of high viscosity) may require additives (fluxes) introduced to the carbon feedstock. The purpose of additives is to lower slag melting temperature and viscosity, causing the slag to flow and exit the gasifier. When slag additives are used, they can permit gasification to occur at a lower temperature. If a lower gasification temperature is used, it will reduce corrosive wear of protective liner materials in the gasification chamber, assuming that the additives do not bring about increased liner material corrosion. Ash quantity and chemistry vary greatly with the carbon feedstock source, with the quantity (percent of the overall carbon source) being negligible for gas, very low for liquid petroleum, 
Table I. Range of Chemistry Found in over 300 U.S. Coal Slags Due to Mineral Impurities ${ }^{[4]}$

Weight Percent

\begin{tabular}{lcccc}
\cline { 2 - 5 } Material & Maximum & Minimum & Average & $\begin{array}{c}\text { Standard } \\
\text { Deviation }\end{array}$ \\
\hline $\mathrm{SiO}_{2}$ & 68.5 & 7.1 & 43.6 & 16.4 \\
$\mathrm{Al}_{2} \mathrm{O}_{3}$ & 38.6 & 4.1 & 25.2 & 10.2 \\
$\mathrm{Fe}_{2} \mathrm{O}_{3}$ & 69.7 & 2.1 & 17.0 & 11.2 \\
$\mathrm{CaO}$ & 45.1 & 0.5 & 5.8 & 6.6 \\
$\mathrm{MgO}$ & 8.0 & 0.1 & 1.2 & 1.1 \\
$\mathrm{~K}_{2} \mathrm{O}$ & 3.5 & 0.2 & 1.4 & 0.7 \\
$\mathrm{Na}_{2} \mathrm{O}$ & 6.5 & 0.3 & 0.9 & 0.6 \\
$\mathrm{TiO}_{2}$ & 3.7 & 0.4 & 1.4 & 0.8 \\
\hline
\end{tabular}

and typically less than 1 pct for petcoke and 10 pct for coal. Biomass, which is being considered as a future carbon feedstock, has ash content varying from 1 to 20 pct and has widely varying chemistry. Containment materials for the severe gasification environment of temperature, ash chemistry, abrasion, and reducing gases are called refractories, which are the focus of this research.

\section{B. Carbon Feedstock Slag Chemistry}

Slagging gasifiers using air cooling can process 1250 metric tons/day or more of a carbon feedstock, producing 90 metric tons or more tons per day of slag waste, depending on the carbon feedstock and its ash content. Ideal gasification occurs in a narrow temperature range that allows ash to liquefy into slag that flows from the gasifier, yet is at a temperature low enough to minimize chemical interactions with the refractory liner. Because ash chemistry and quantity can vary greatly, understanding and controlling slag chemistry for optimum gasifier operation (defined here as producing the desired syngas composition with the longest refractory service life) is critical. Two types of carbon feedstock are commonly used in gasification, coal and petcoke, with biomass feedstock considered in future applications and not the subject of this article. A range of coal ash chemical compositions for approximately 300 U.S. coals $^{[4]}$ from across the United States are presented in Table I and illustrate the wide chemistry variations that exist. With regard to the compounds listed, $\mathrm{Fe}, \mathrm{Si}, \mathrm{Ca}$, and $\mathrm{Al}$ are the most common elements of concern related to refractory corrosion and wear. These elements also have a large impact on slag viscosity, which influences slag penetration into the pores of the refractory lining and refractory corrosion. Iron oxide, for example, influences slag viscosity, refractory penetration, and refractory corrosion, interacting with $\mathrm{Cr}_{2} \mathrm{O}_{3}$ and $\mathrm{Al}_{2} \mathrm{O}_{3}$ in the refractory grain to form either a solid solution or a spinel, or causing its dissolution in the slag. Other elements such as $\mathrm{Na}$ and $\mathrm{K}$ may be of concern depending on their quantity in a slag.

Petcoke slags contain most major elements found in coal slag but have higher levels of $\mathrm{V}$ and $\mathrm{Ni}$. The average range of chemistry for a limited number (nine) of petcoke slags $^{[5-7]}$ is given in Table II. Slags with high
Table II. Range of Chemistry Found in Nine Petcoke Slags Due to Impurities ${ }^{[5-7]}$

\begin{tabular}{lcccc}
\hline & \multicolumn{4}{c}{ Weight Percent } \\
\cline { 2 - 5 } Material & Maximum & Minimum & Average & $\begin{array}{c}\text { Standard } \\
\text { Deviation }\end{array}$ \\
\hline $\mathrm{SiO}_{2}$ & 18.9 & 3.1 & 14.1 & 8.7 \\
$\mathrm{Al}_{2} \mathrm{O}_{3}$ & 9.4 & 0.5 & 4.8 & 2.8 \\
$\mathrm{Fe}_{2} \mathrm{O}_{3}$ & 31.6 & 1.2 & 7.2 & 9.3 \\
$\mathrm{CaO}$ & 11.9 & 2.0 & 5.4 & 3.8 \\
$\mathrm{MgO}$ & 5.1 & 0.3 & 1.0 & 1.6 \\
$\mathrm{~K}_{2} \mathrm{O}$ & 0.7 & 0.3 & 0.5 & 0.4 \\
$\mathrm{Na}_{2} \mathrm{O}$ & 2.3 & 0.1 & 0.8 & 0.8 \\
$\mathrm{TiO}_{2}$ & 0.6 & 0.2 & 0.3 & 0.2 \\
$\mathrm{NiO}$ & 11.4 & 2.9 & 8.4 & 3.2 \\
$\mathrm{~V}_{2} \mathrm{O}_{5}$ & 79.4 & 30.2 & 57.0 & 19.5 \\
\hline
\end{tabular}

levels of $\mathrm{V}$ are a concern because of the large number of valences the element can have, depending on gasification temperature and oxygen partial pressure. In general, petcoke slags are considered by gasifier operators to have behavior similar to coal slags, although on a microscopic level, differences exist between the refractory/slag interactions within the refractory microstructure. The focus of refractory research in this article will not include vanadium compounds, which have limited thermodynamic databases for high-temperature and low oxygen partial pressure environments, making modeling conditions in gasification difficult to impossible.

\section{Impact of Refractory Lining Wear}

The slag and gasifier environment are core issues determining the gasifier lining's refractory service life and, thus, its on-line availability. The failure of a refractory lining is expensive, both in terms of the refractory replacement cost $(\geq \$ 1$ million U.S. dollars, depending on gasifier size and the extent of rebuild required) and also in terms of lost production time. Relining a gasifier requires that it be completely shut down and, under the best of circumstances, takes about 10 days for a partial rebuild and longer for a complete rebuild. The process involves gasifier cooldown (up to 4 days), removal of the existing lining ( 1 to 3 days depending on the extent of refractory repair necessary), and repair/rebuild ( 3 days for a partial repair and 7 to 10 days or longer for a full rebuild, depending on the extent of repairs necessary). Some gasification sites maintain a second gasifier to ensure steady syngas production. When one gasifier is shut down for maintenance, the second rebuilt gasifier, operating in standby mode, is placed on line. This results in reduced system downtime and increased on-line service and availability to downstream operations. The second gasifier, however, increases capital and maintenance costs. Even with a second gasifier, the time to switch to a second system can vary from hours to days, depending on if the spare gasifier is available and in the preheat mode.

Because of the long down times required for repair, gasifier operators would like to install refractory linings with a reliable life of at least 3 years and have identified 


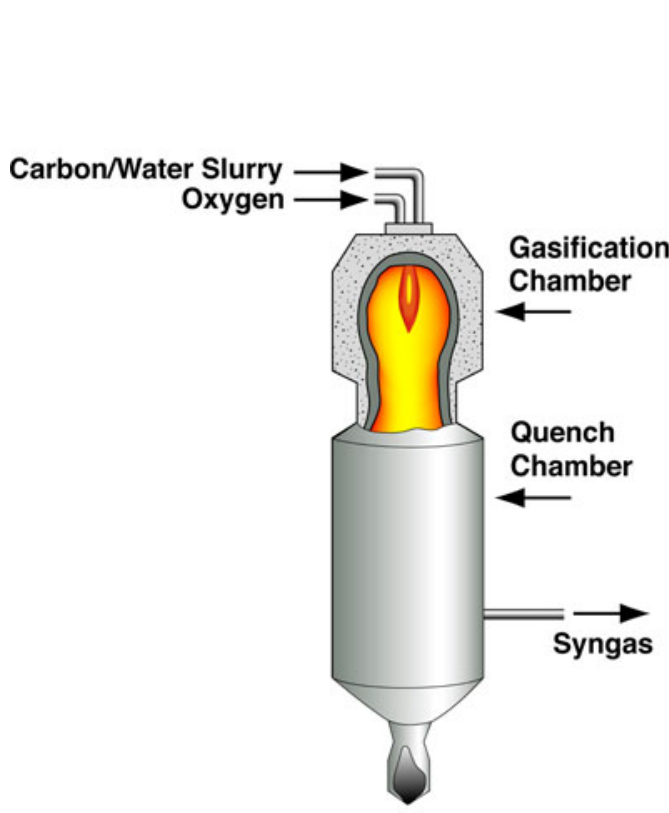

(a)

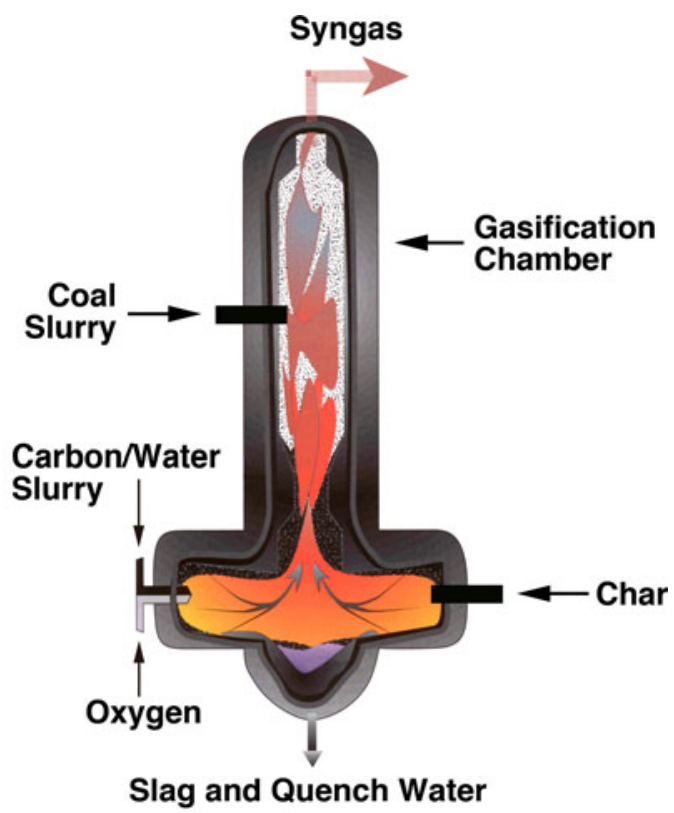

(b)

Fig. 2-Two types of air-cooled slagging gasifiers using refractory liners: $(a)$ GE design and (b) ConocoPhillips design.

refractory service life as a key barrier to widespread commercialization of gasification technology. ${ }^{[8]}$ The current generation of refractory liners in slagging gasifier systems has yet to meet this service life, failing in as little as 3 months in high-wear areas while approaching the desired 3-year service life in other locations. Reliable refractory liners with improved service life are needed to ensure that gasification fulfills its potential as a clean and efficient means of generating power and producing precursor gas streams. Gasifier users need system availability of 85 to 95 pct for utility applications and more than 95 pct in applications such as chemical feedstock production. ${ }^{[9]}$ Failure to meet these goals has impacted the commercial use of gasification technology.

\section{Gasifier Liner Technology}

The material challenges for the refractory liner in an air-cooled slagging gasifier are severe and include the following: elevated temperature, large or rapid changes in temperature, erosion by particulates, molten slag attack, slags of variable composition, attack by hot corrosive gases, and variable oxidizing or reducing conditions. ${ }^{[10-12]}$ As mentioned, refractory materials that can withstand a gasifier environment for long periods of time are necessary for a continuous, efficient, and reliable gasification process. Two of the slagging gasifier designs that are the focus of this research are shown in Figure 2.

Refractory linings used in gasifiers are between two and six layers, ${ }^{[13]}$ with a typical air-cooled lining cross section composed of four layers, as shown in Figure 3. The hot face or working lining is designed for direct contact with the gasification environment, with the composition dependent not just on the gasifier atmosphere and feedstock, but also on the temperature and location in the gasifier where the material is used. The most critical refractory properties are that it be thermodynamically stable to hot gases such as $\mathrm{H}_{2}, \mathrm{CO}$, $\mathrm{CO}_{2}, \mathrm{H}_{2} \mathrm{O}$, or $\mathrm{H}_{2} \mathrm{~S}$; that it withstand hot abrasion of molten slag; that it be chemically resistant to liquefied ash from the carbon feedstock; and that it withstand thermal cycling. Because of the number of slag components and the complicated microstructure of gasifier refractories, the use of existing phase diagrams or thermodynamic data to predict refractory/slag interactions is of limited value. Few phase diagrams of relevance beyond three components were created, and thermodynamic databases for use in the high-temperature oxidizing/reducing environment with the number of compounds in a slag are incomplete or do not exist for all interactions of interest. Limited information also exists on the ability of a refractory material to withstand the high-temperature particulate impact/abrasive associated with the injected feedstock. Other material properties, such as the thermal conductivity of the refractory lining, must be considered so gasifier shell temperature is maintained at an acceptable internal temperature for slag flow, yet keeps the steel shell and refractory insulation above the acid dew point condensation temperature. If dew point condensation occurs within the gasifier, it could result in shell corrosion and catastrophic gasifier failure due to the high pressure used in gasification.

Gasifier refractory designs fall into two types of gasification systems: (1) gas and liquid feedstock gasifiers (typically low ash) and (2) solid feedstock gasifiers (typically higher ash). The emphasis on liner materials is on the hot-face refractory materials, which are exposed to the most aggressive environment and, therefore, exhibit the most aggressive wear/corrosion. 


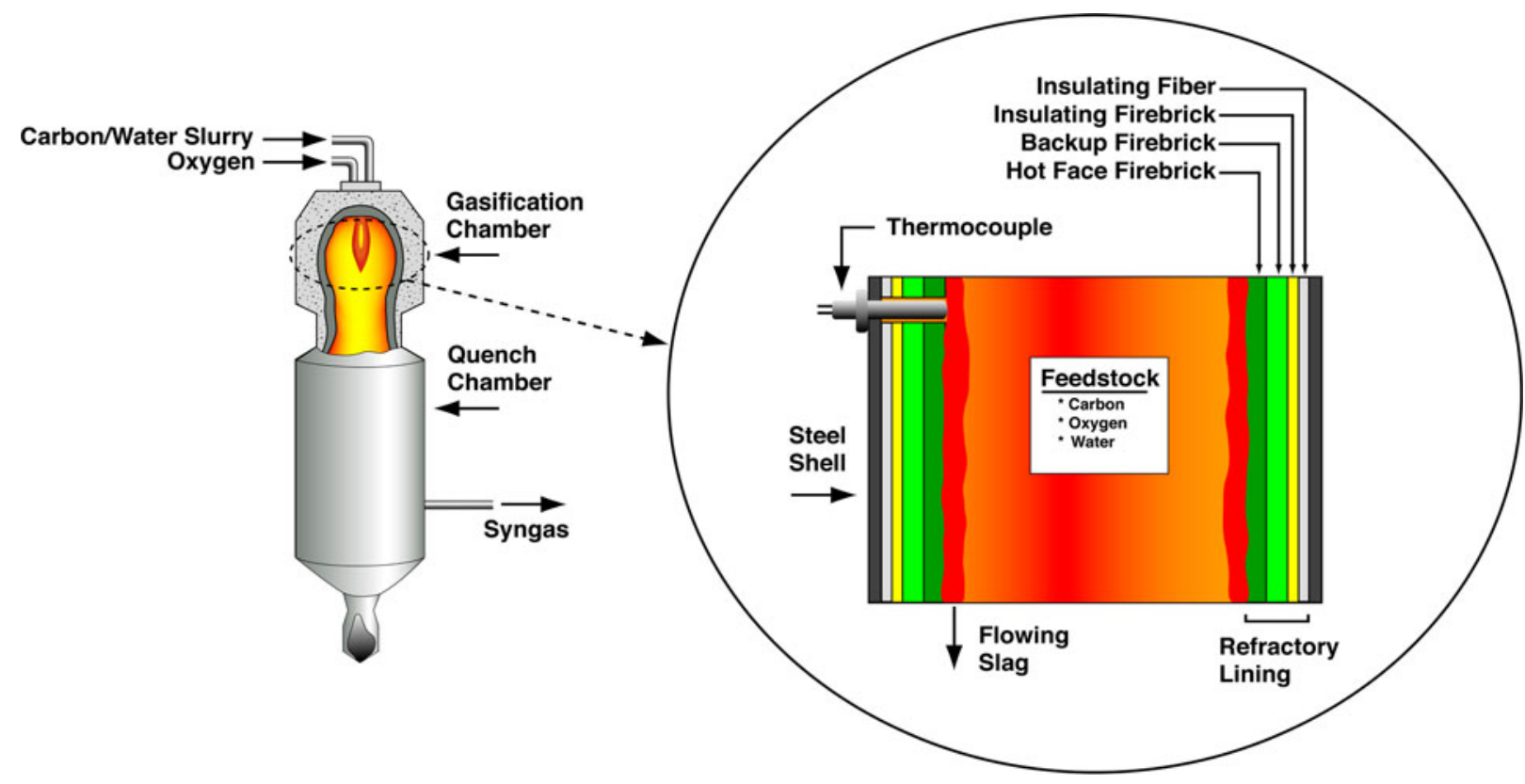

Fig. 3-Type of air-cooled slagging gasifier with a cross section showing slag flow down hot-face refractories common to these types of gasifiers.

\section{E. Refractories for Low Slag Environment (Gas or Liquid Feedstock)}

In the low-slag environment of gas or liquid gasifier feedstock, high-alumina refractories low in $\mathrm{SiO}_{2}$ and $\mathrm{FeO}$ were found to perform best. The low $\mathrm{SiO}_{2}$ and $\mathrm{FeO}$ levels are important because these components can interact with syngas. Hydrogen reduction of $\mathrm{SiO}_{2}$ occurs above $1253 \mathrm{~K}\left(980{ }^{\circ} \mathrm{C}\right)$, causing the formation of $\mathrm{SiO}$ vapor, which migrates to other locations in the refractory lining. ${ }^{[14]}$ The $\mathrm{SiO}_{2} / \mathrm{H}_{2}$ reaction becomes very likely at temperatures above $1473 \mathrm{~K}\left(1200^{\circ} \mathrm{C}\right)^{[15]}$ and is impacted by brick porosity, gasifier pressure, and feedstock throughput. Silica volatilization was found to occur mainly at the hot face of a gasifier liner, where refractory bond strength can be adversely impacted. Iron oxide in alumina refractories used with gas or liquid feedstock is kept low because it catalyzes the Boudouard reaction $\left(2 \mathrm{CO} \rightarrow \mathrm{CO}_{2}+\mathrm{C}\right),{ }^{[14]}$ leading to the buildup of carbon in a refractory. The Boudouard reaction occurs as low as about $783 \mathrm{~K}\left(510{ }^{\circ} \mathrm{C}\right)$, maximizes by $843 \mathrm{~K}\left(570{ }^{\circ} \mathrm{C}\right)$, and nearly disappears by $1003 \mathrm{~K}\left(730^{\circ} \mathrm{C}\right) \cdot{ }^{[15]}$ The carbon buildup leads to the formation of free layers of $\mathrm{C}$ or $\mathrm{Fe}_{2} \mathrm{C}$ at joints, pores, voids, or cracks, causing structural weakening of the refractory, thermal expansion mismatches, or increased or nonuniform heat transfer to the gasifier shell.

Typical failure mechanisms found in gasifiers having a gas or liquid feedstock include thermal expansion or irreversible creep deformation, ${ }^{[14]}$ which occurs during rapid thermal cycling and leads to surface spalling or joint failure. Refractory linings in gasifiers with gas or liquid feedstock last much longer than the 2 to 3 years experienced with coal or petcoke (slagging) feedstock, and are currently not viewed as areas requiring research. When a monolithic lining is used with gas or liquid carbon feedstock, anchors that attach the lining to the shell can experience failure from mechanical stresses, metal fatigue, or corrosion, leading to gaps between the refractory shell and the lining. These gaps impact heat transfer and can initiate other failure mechanisms due to the heat buildup at those sites. Monolithic materials such as castables, however, are seeing increased usage in low slag gasifiers for many reasons, including fewer bonds and increased speed of installation. ${ }^{[14]}$

\section{F. Refractories for Solid Feedstock Gasifiers (Typically Coal or Petcoke)}

A number of refractory compositions were considered or evaluated for slagging gasifier environments using coal or petcoke feedstock before current liner materials were selected, and include sintered or fused cast alumina-silicate, high alumina, chromia-alumina, chromemagnesia, alumina, and magnesia, as well as $\mathrm{SiC}$ refractory materials. ${ }^{[16-20]}$ Laboratory research was used to evaluate the performance of early liner materials by simulating the gasifier environment to determine corrosive interactions between slag and refractory. This research is traceable back to the 1970s and 1980s, and was funded by the USDOE, the Electric Power Research Institute (EPRI), and private industry. ${ }^{[10-12,16-19,21,22]}$ Refractory microstructures containing $\mathrm{SiC}$ and $\mathrm{Si}_{3} \mathrm{~N}_{4}$, for example, were found to react with components of the gasifier slag, causing severe material wear. Silicon carbide in the refractory and $\mathrm{FeO}$ in the slag react to form reactive gases such as $\mathrm{CO}$, the potential for $\mathrm{SiO}$ or $\mathrm{SiO}_{2}$ formation, and metallic iron, all of which can lead to rapid refractory degradation and material loss. Fused-cast refractories (with little or no porosity) interacted with slag at a slower rate, but had thermal shock issues due to gasifier cycling or shutdown, leading to higher wear rates than with porous materials. 
Alumina refractories are not used in slagging gasifiers with coal or petcoke feedstock because of potential corrosive interactions between the liquid ash and the refractory. Vanadium found in petcoke slags can aggressively attack alumina refractories, rapidly decreasing service life. When vanadium is present as $\mathrm{V}_{2} \mathrm{O}_{3}$ (one of several stable phases present in the reducing environment of a gasifier depending on its oxygen partial pressure), it has a melting temperature of about $2243 \mathrm{~K}\left(1970{ }^{\circ} \mathrm{C}\right.$ ); however, $\mathrm{V}_{2} \mathrm{O}_{5}$ (a stable phase present in atmospheric oxygen partial pressure) melts at about $953 \mathrm{~K}\left(680{ }^{\circ} \mathrm{C}\right)$. Initial liquid formation between $\mathrm{V}_{2} \mathrm{O}_{3}$ and $\mathrm{Al}_{2} \mathrm{O}_{3}$ occurs at about $1993 \mathrm{~K}\left(1720{ }^{\circ} \mathrm{C}\right)$, while between $\mathrm{V}_{2} \mathrm{O}_{5}$ and $\mathrm{Al}_{2} \mathrm{O}_{3}$, it occurs at about $913 \mathrm{~K}$ $\left(640{ }^{\circ} \mathrm{C}\right)$. Because of the low temperature at which liquid occurs between $\mathrm{V}_{2} \mathrm{O}_{5}$ and $\mathrm{Al}_{2} \mathrm{O}_{3}$ phases, rapid reactions between slag and refractory can occur in air, which can lead to excessive refractory wear in a short period. In practice, the valence of vanadium should not be an issue except during gasifier preheat or cooldown, when high oxygen partial pressures are present and $\mathrm{V}_{2} \mathrm{O}_{5}$ formation can occur. Poor mixing of the carbon feedstock and oxygen in a gasifier, however, could lead to isolated environments and uneven refractory wear. With using chrome oxide refractory liners in slagging gasifiers, gasifier operators generally think that vanadium oxide acts similar to iron oxide, with comparable wear rates. Potential differences in the wear rate of high chrome oxide refractories caused by slags rich in iron oxide or vanadium oxide were observed in laboratory testing, but have not been reported in commercially exposed samples; so they are not the subject of this article. ${ }^{[23]}$

On the basis of laboratory testing and hands-on experience of gasifier users, chrome oxide refractories were determined to have the best overall properties for hot-face refractory materials, with compositions containing $\mathrm{Cr}_{2} \mathrm{O}_{3}-\mathrm{Al}_{2} \mathrm{O}_{3}, \mathrm{Cr}_{2} \mathrm{O}_{3}-\mathrm{Al}_{2} \mathrm{O}_{3}-\mathrm{ZrO}_{2}$, and $\mathrm{Cr}_{2} \mathrm{O}_{3}$ $\mathrm{MgO}$ found to have the best performance. ${ }^{[10,20,24]}$ Examples of typical high chrome oxide compositions used in industry are listed in Table III. Composition "C," a formulation containing $\mathrm{Cr}_{2} \mathrm{O}_{3}-\mathrm{MgO}$, has been greatly limited or discontinued in the United States because of concerns over possible hexavalent chrome

Table III. Chemical Composition and Physical Properties of Commonly Used High Chrome Oxide Refractories Used in Air-Cooled Slagging Gasifiers

\begin{tabular}{lccc}
\hline & \multicolumn{3}{c}{ Brick Type } \\
\cline { 2 - 4 } Chemistry (Wt Pct)* & $\mathrm{A}$ & $\mathrm{B}$ & $\mathrm{C}$ \\
\hline $\mathrm{Cr}_{2} \mathrm{O}_{3}$ & 89.0 & 87.3 & 81.0 \\
$\mathrm{Al}_{2} \mathrm{O}_{3}$ & 10.2 & 2.5 & 0.4 \\
$\mathrm{ZrO}_{2}$ & - & 5.2 & $\mathrm{NR}$ \\
$\mathrm{MgO}$ & $\mathrm{NA}$ & $\mathrm{NA}$ & 17.0 \\
$\mathrm{Bulk}$ density* $\left(\mathrm{g} / \mathrm{cm}^{3}\right)$ & 4.21 & 4.07 & 3.95 \\
Porosity* $(\mathrm{vol}$ pct) & 16.7 & 16.5 & 12.0 \\
$\mathrm{CCS}$ (MPa) & 48.3 & 66.9 & 40.0 \\
\hline \multicolumn{2}{c}{ *Data from manufacturer's technical data sheets. } \\
NR = not reported. \\
$\mathrm{CCS}=$ cold compressive strength. \\
\hline
\end{tabular}

formation. Thermodynamic research has shown that levels of alkali and alkaline earth materials normally encountered in coal or petcoke, or that would occur in potential mixtures of biomass and western coal slags (materials naturally high in alkali and alkaline earth compounds), would not cause the formation of hexavalent chrome oxide at a level to be a concern. ${ }^{[25]}$ The reason for this is related to oxygen partial pressure, which causes hexavalent chrome oxide to form at very low levels of the gasification process $\left(10^{-6}\right.$ to $\left.10^{-9} \mathrm{~atm}\right)$.

Because of cost and performance considerations associated with the high chrome oxide refractories, zoning (the use of refractories with different compositions and properties in different areas of the gasifier) is practiced at many gasifier sites. Originally, a minimum of 75 pct $\mathrm{Cr}_{2} \mathrm{O}_{3}$ in a refractory was thought necessary to give sustained lining performance. ${ }^{[26]}$ Improvements in refractory technology and a better understanding of gasifier wear allowed $\mathrm{Cr}_{2} \mathrm{O}_{3}$ levels as low as 60 pet to be used in gasifier locations experiencing low wear (dome or some areas of the sidewall), with $\mathrm{Cr}_{2} \mathrm{O}_{3}$ levels as high as 95 pct used in the severe wear areas (sidewall or slag exit locations). Selection of a refractory is based, in part, on the performance of the refractory (which is related to the chrome content) and on the cost of the material (with higher chrome oxide content typically costing more). At many gasifier locations, the performance and cost of the higher chrome oxide material does not justify its use. As mentioned, even with improvements in material technology, service life of the hot-face $\mathrm{Cr}_{2} \mathrm{O}_{3}$ $\mathrm{Al}_{2} \mathrm{O}_{3}$ and $\mathrm{Cr}_{2} \mathrm{O}_{3}-\mathrm{Al}_{2} \mathrm{O}_{3}-\mathrm{ZrO}_{2}$ compositions is limited to between 3 and 36 months.

The backup refractory lining (behind the high chrome oxide hot face, as shown in Figure 3 ) is an alumina/ chrome refractory (approximately 90 pct $\mathrm{Al}_{2} \mathrm{O}_{3} / 10$ pct $\mathrm{Cr}_{2} \mathrm{O}_{3}$ ). The purpose of this lining is to slow slag corrosion in case of primary lining failure. The backup lining also controls the gasifier shell temperature during periods of normal gasifier operation. The final brick layer of the gasifier lining is a monolithic or firebrick material, as shown in Figure 3. This layer, along with a layer of fiber insulation, is located adjacent to the gasifier steel containment shell where it provides insulation and controls the gasifier shell temperature. Because the syngas environment is high in $\mathrm{H}_{2}$, which has a thermal conductivity about 7 times that of air, low-porosity linings are used as insulating material even though it has a much higher density and thermal conductivity in air than insulating firebrick. ${ }^{[14]}$ Pores of high porosity refractory become filled with syngas, resulting in a thermal conductivity that can be 1.5 to 2 times that of air (assuming a 50 pct $\mathrm{H}_{2}$ syngas atmosphere). For this reason, low-porosity firebrick material can have better insulating properties than traditional high porosity insulating refractory liners. Super-duty (mullite) or high-alumina refractory materials are typically used. ${ }^{[13]}$

The last layer of refractory lining material is located between the insulating refractory brick and the steel shell (Figure 3). This layer allows for expansion/movement of the refractory lining, in both the circumferential and vertical dimensions. This layer is a fibrous ceramic 
material, which absorbs expansion/contraction differences between the steel shell and the refractory lining. A maximum 70 to 75 pct compression factor is used in this layer to allow fiber flexibility, yet does not allow for hot spots or permanent shaping of the fiber from overcompression. The fiber layer is important because it allows for expansion of unsupported structure lengths in the high-pressure vessels, limiting expansive stresses in the gasifier shell.

High chrome oxide refractory liners currently used as liners in slagging gasifiers were developed based on coal and petcoke carbon feedstock. Future carbon feedstock under consideration for slagging gasifiers includes biomass and coals from the western United States, materials that are high in alkali and alkaline earth oxides. If used individually or combined in mixtures with coal or petcoke, slags from these materials may have different corrosion mechanisms and may require different refractory liners from the high chrome/aluminum/zirconium oxide refractories currently used. An example of a nontraditional carbon feedstock under consideration is black liquor, a by-product from Kraft paper production. ${ }^{[27,28]}$ This material was evaluated as a carbon feedstock in gasification to recover potential heat from the carbon it contains and to recover green liquor used to regenerate pulping chemicals. Sodium carbonate and sodium sulfide are generated in the gasifier (along with other by-products) from the black liquor, which contact the refractory liner, causing its wear and eventual failure. Chrome oxide liners were one of several refractory compositions considered as liners in the experimental gasifier, but had performance related issues. ${ }^{[28]}$ In laboratory testing and in preliminary field testing, a fusion-cast commercial refractory made of magnesiumaluminum spinel was found to perform best, and was thought to provide the desired 2-year service life necessary for this application. Unfortunately, research on this type of gasifier was discontinued.

It is apparent that when using the current carbon feedstock of coal or petcoke with the different refractory layers of Figure 3, the hot-face lining experiences wear issues that impact gasifier on line service. In order to improve the performance of existing high-chrome oxide refractory materials used in the hot-face lining or to develop new, improved performance compositions, postmortem analyses to determine the causes of failure of existing refractory materials at several commercial gasifier sites are necessary and were preformed.

\section{ANALYSIS OF FAILURE HIGH CHROME OXIDE REFRACTORIES IN SLAGGING GASIFIERS}

\section{A. Refractory Failures}

Based on discussions with gasifier users/operators, observations of failed refractories at different gasifier sites, and postmortem analyses of failed refractories, a flow sheet categorizing the flow causes of refractory failure (Figure 4) was developed. The causes of refractory failure include gasifier design (air $v s$ water quench in the lower cone/slope area), how the gasifier was operated (material throughput, temperature, and number of thermal cycles per campaign), the composition of the refractory and how it withstands chemical corrosion/ physical wear, the quality of the refractory (internal flaws or exterior dimensions), and how well the refractory material was installed. Each of these varies over time and at different gasifier sites. The most common and catastrophic causes of refractory failure were found to be chemical corrosion and spalling, although other causes such as burner misalignment or refractory installation can be problematic and can lead to rapid lining failure.

As viewed from the interior of a gasifier, an example of high chrome oxide refractory wear on the gasifier sidewall, dominated by chemical corrosion and spalling, is shown in Figure 5. Chemical corrosion involves the dissolution of refractory material into the slag as it flows

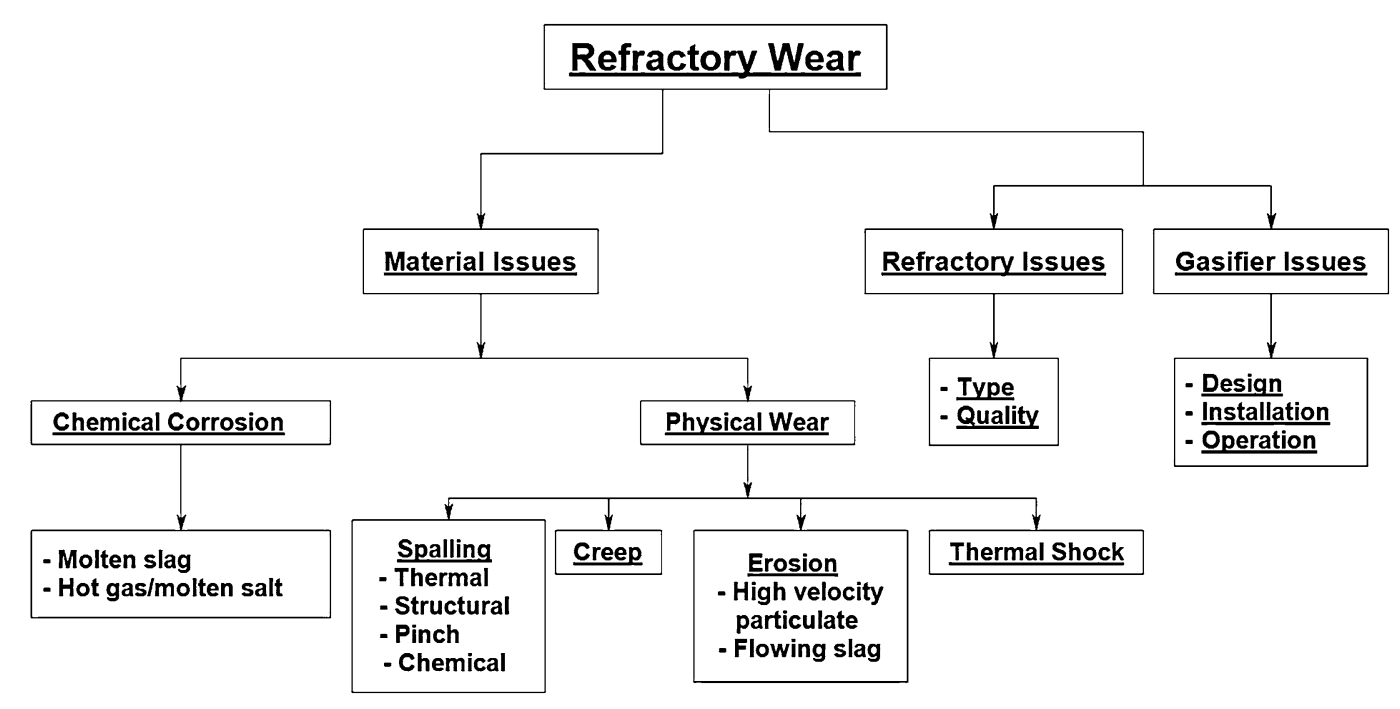

Fig. 4-Refractory wear flow sheet based on discussion, observation, and postmortem analysis of spent air-cooled slagging gasifier refractories. 


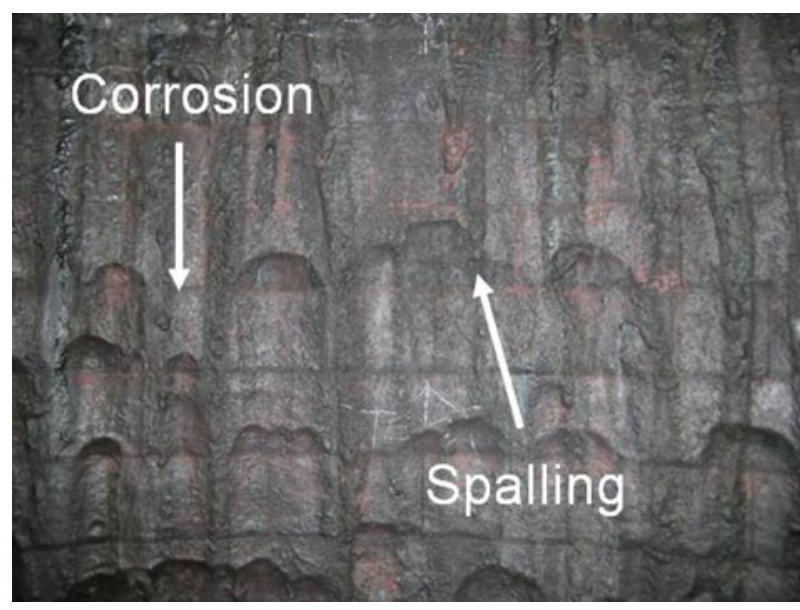

Fig. 5-High chrome oxide sidewall refractories in a slagging gasifier indicating surface corrosion and spalling.

over or penetrates refractory pores. Corrosion within the pores can lead to the removal of refractory particles or grains as the intergranular bond phase is weakened. Chrome oxide, which can make up to 95 wt pct of a refractory's overall composition, is an excellent liner material because it interacts with specific components of the gasifier slag, forming high melting phases, and because it increases the viscosity of the slag by interacting with components in it. Chrome oxide has a very low solubility in the slag. Because of its very high chemical resistivity and because of how it interacts with slag, refractory bricks of this type have a longer refractory service life than most other refractory oxides in gasifiers.

Hot-face chrome oxide refractories are sintered from a mixture of controlled particle size grains (typically from a maximum of $3 \mathrm{~mm}$ down to about $45 \mu \mathrm{m}$ in size) and have a porosity ranging from 14 to 17 pct. The porosity aids in the thermal shock resistance of the refractory, but is also the indirect cause of structural spalling. The porous nature of chrome oxide refractories and the small thermal gradient from the hot face to the cold face of the brick (about $373 \mathrm{~K}\left(100^{\circ} \mathrm{C}\right)$ ) allows slag to penetrate deep within the refractory surface, setting up the basis for structural spalling. Figure 6 illustrates how corrosion and spalling influence overall refractory wear, ${ }^{[26]}$ with a gradual corrosion rate caused by chemical dissolution (close to horizontal slope), rapid lining wear caused by structural spalling or chemical spalling (vertical slope areas), and the combined effects creating a significantly higher wear rate $v s$ by chemical dissolution alone (combined slope area, which is a dashed line). Hot-face spalling that occurs during a gasifier operation is not uniform, as noted by the irregular surface wear in Figure 5.

Wear and slag penetration in the cross section of a $90 \mathrm{wt}$ pct chrome oxide refractory liner material removed from a gasifier (cross section goes from the hot face (top) to the cold face (bottom)) caused by both structural spalling and chemical corrosion is shown in Figure 7. Note that slag penetrated deep within the refractory and that cracks formed near the hot face of the refractory where slag penetrated refractory pores

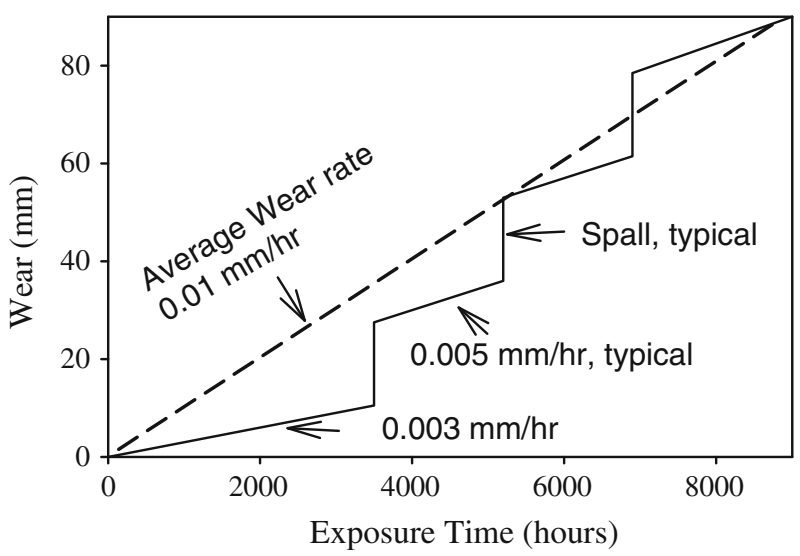

Fig. 6 - Combined wear of chemical dissolution and structural spalling in high chrome oxide gasifier refractories (actual wear will vary from what is shown). ${ }^{[26]}$

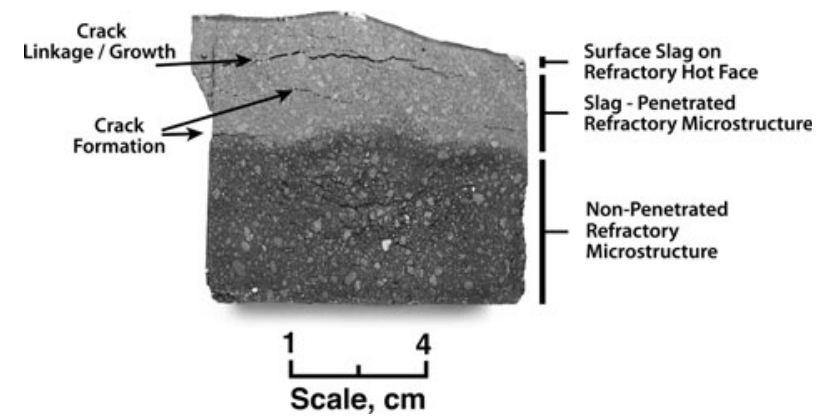

Fig. 7-Cross section of a refractory showing slag corrosion and penetration leading to crack formation, a precondition for structural spalling.

and close to the slag penetrated/nonpenetrated layer. Crack formation is the basis for structural spalling and typically originates in or near the slag penetrated/ nonpenetrated layer. Slag penetration is determined by its chemistry, the ability of the slag to "wet" the refractory, its viscosity, and the temperature profile across the refractory (influenced by the thermal conductivity of the refractory). Once cracks form, they can link (coalesce), resulting in refractory layers, up to $25-\mathrm{mm}$ thick, that can spall off from the hot face. Structural spalling is exacerbated by thermal cycling of the gasifier, which occurs about every 30 to 45 days. Work has been done to predict spalling wear ${ }^{[29]}$ using modeling.

Examples of spalled refractory flowing down the sidewall of a gasifier and spalled refractory material (after removal from a gasifier) are shown in Figure 8. Note that the spalled refractory sliding down the refractory sidewall (circled in yellow in Figure 8(a)) is thin. It was removed from the gasifier and is shown in Figure $8(\mathrm{~b})$. This spalled refractory is approximately 5-mm thick, while the thick spalled refractory sample shown in Figure 8(c) is approximately $20-\mathrm{mm}$ thick and came from a different gasifier. It is not known why the thickness of these two spalled materials is different, but factors such as the temperature of operation, the length of uninterrupted service, the speed of a gasifier 


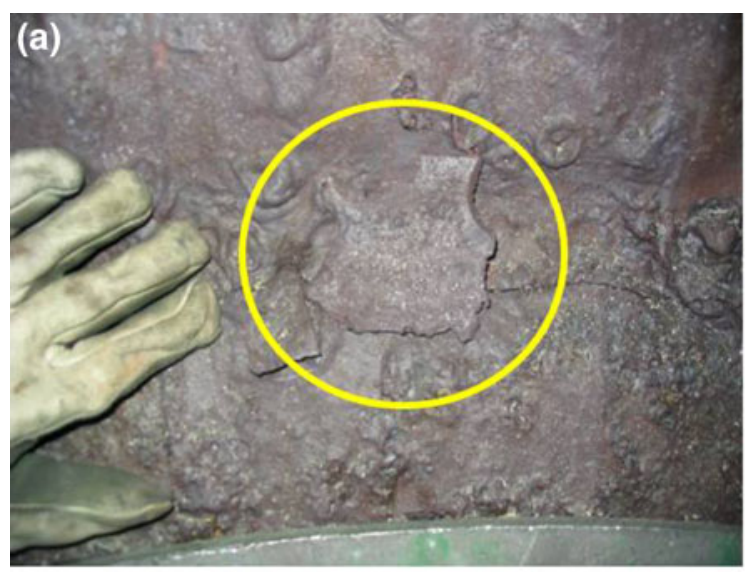

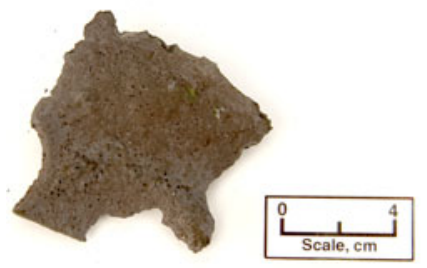

(b)



(c)
Fig. 8-Examples of refractory wear caused by slag dissolution and spalling. (a) Flowing slag is causing chemical dissolution of the refractory sidewall and refractory material spalling (circled fragment). (b) Thin spalled refractory approximately 5 -mm thick shown in (a). (c). Thick spalled refractory approximately $20-\mathrm{mm}$ thick.

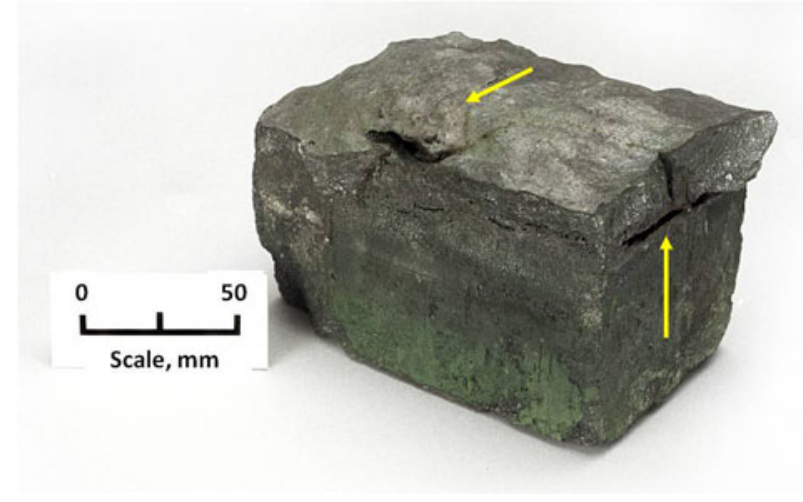

Fig. 9-Refractory surface in the process of spalling (yellow arrows point to spalled material).

shutdown/heatup, the number of heatup/cooldown cycles, and at what stage spalled material is released from the brick surface influence how spalling and corrosion occur.

A refractory brick in the process of spalling was removed from a gasifier lining and is shown in Figure 9. Note that this brick has two locations in the process of spalling: a thin layer on the surface (indicated by the upper arrow) and a thicker area (indicated by the lower arrow) that is a greater distance from the refractory hot face. It is thought that the thin sample on the refractory surface (Figures 8(a) and (b)) may have initiated as a thicker specimen that gradually wore thinner by surface

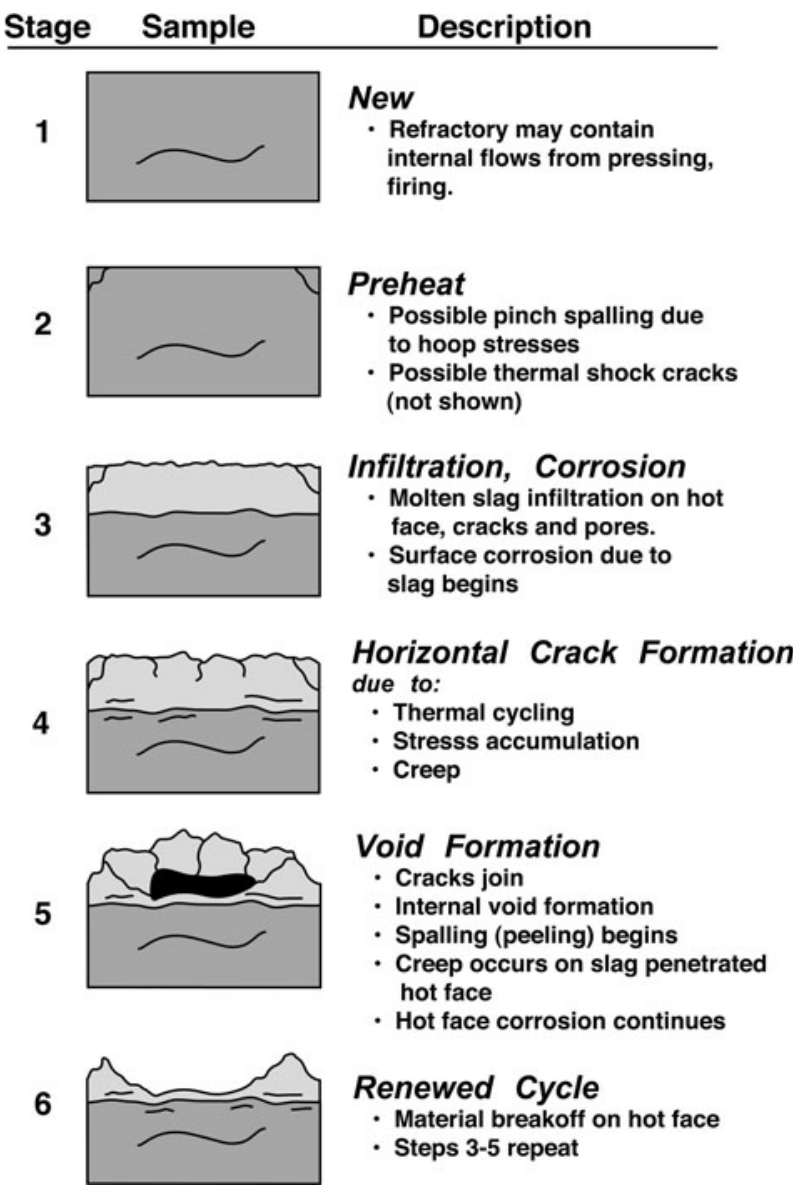

Fig. 10 - Stages of refractory wear in high chrome oxide refractories used in slagging gasifiers.

corrosion before becoming dislodged from the surface (through spalling). As long as a spalled refractory remains in place, it will wear by corrosion, protecting refractory material underneath it. Spalling is exacerbated by rapid gasifier cycling, which causes portions of the refractory hot face to be continuously and rapidly removed, decreasing overall refractory service life vs the slow wear process brought about by only chemical dissolution. ${ }^{[26]}$ The mechanism of refractory slag attack on a high chrome oxide refractory is shown in Figure 10.

An overview of air-cooled slagging gasifier wear based on postmortem evaluations made in one type of commercial gasifier is discussed in the following gasifier sections: (1) dome, (2) sidewall, and (3) lower cone. These areas of the gasifier are shown in Figure 3 and correspond to where carbon feedstock is injected in the gasifier (dome), the vertical sidewall, and the base where slag and syngas exit the gasifier (lower cone).

\section{B. Dome Lining Failure}

The dome is located at the top of the GE type gasifier (Figure 2(a)) and is where the carbon feedstock, oxygen, and water used to produce syngas are injected into the gasifier. The lining used in the dome can have a chrome oxide content as high as 95 pct, with a service varying 


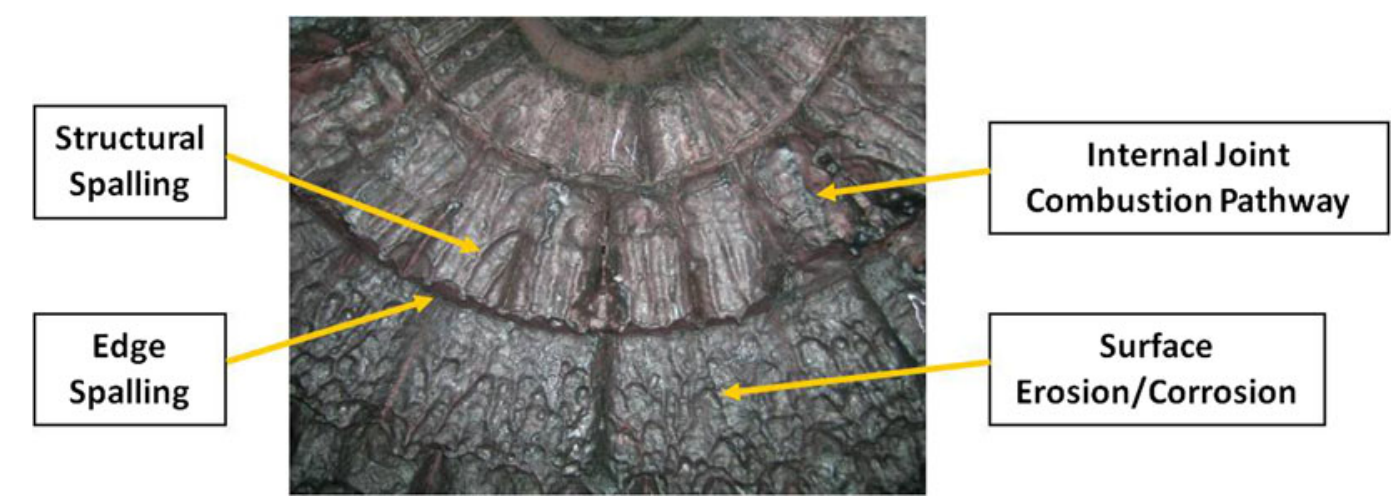

Fig. 11-Dome of an air-cooled slagging gasifier showing the hot-face refractories and causes of wear.

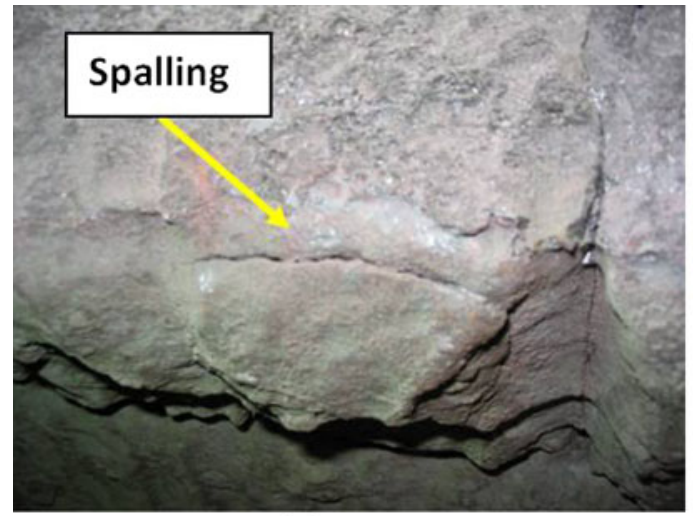

(a)

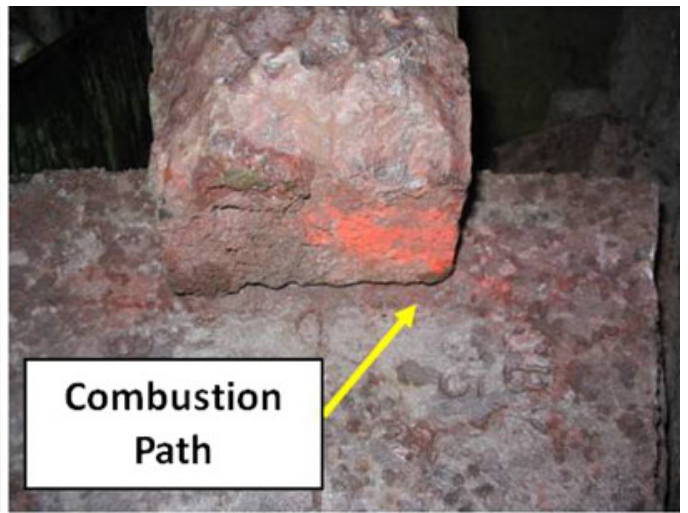

(b)

Fig. 12-Dome hot-face refractories. (a) Side view showing spalling where bricks join and showing surface spalling in the process of occurring, and $(b)$ path of carbon feedstock that has entered between joints of the refractory, "combusting" between brick layers. Note the different shades of color at the brick joints where slag is present, which is caused by slag iron in different oxidation states in (b). A combustion pathway is evident at the side and base of the bricks. In (b), the single brick on top is from the hot face and the two bricks underneath are from the backup lining.

between 9 and 36 months. Refractory wear in the dome area is shown in Figure 11 and can be caused by the following: surface corrosion/erosion, structural spalling, and spalling at refractory joints.

Much of the irregular surface in the dome area is caused by structural spalling. An example of this is shown in the side view of a dome refractory (Figure 12(a)). A large depression at the refractory brick joint, described as edge spalling, is also evident in Figure 12(a). A number of possible causes exist for the edge spalling and include hoop stresses, refractory material that is slightly out of specification for the dimensions of the dome, a gradual lowering (creep) of the dome during use, or improperly installed refractory materials.

Refractory wear due to the carbon feedstock combustion is noted at some of the refractory brick joint intersections (indicated by an arrow in Figure 11) and by the side view of refractories removed from the dome (Figure 12). The joint defect occurs when carbon feedstock and oxygen penetrate to the back of the dome hot face, "combusting" there, vs reacting within the gasification chamber. Slag from the carbon feedstock is deposited on the refractory surface, which is red in color. The red slag appearance in Figure 12 was caused by an oxygen partial pressure close to theoretical (around $10^{-1} \mathrm{vs}$ the $10^{-8}$ in the gasifier), which lead to the formation of thermodynamically stable $\mathrm{Fe}_{2} \mathrm{O}_{3}$. The red slag is in contrast to the brown slag color in the interior of the gasifier, which is due to the formation of complex iron oxide, such as $\mathrm{Fe}_{3} \mathrm{O}_{4}$, which is the stable thermodynamic state of $\mathrm{Fe}$ in the lower oxygen partial pressure of the gasifier (between about $10^{-4}$ to $10^{-8}$ ).

\section{Sidewall Lining Failure}

Refractory wear on the sidewall of the gasifier has two main causes: chemical corrosion spalling from slag and structural spalling. These two wear mechanisms cause refractory service life on the gasifier sidewall to vary between 9 and 30 months, depending on the gasifier site. Worn gasifier sidewall refractories are indicated in Figure 13 for refractory materials containing about 90 pct chrome oxide. These two photos are from different gasifiers, with differences in surface wear due to factors such as the carbon feedstock, the feed rate, the 


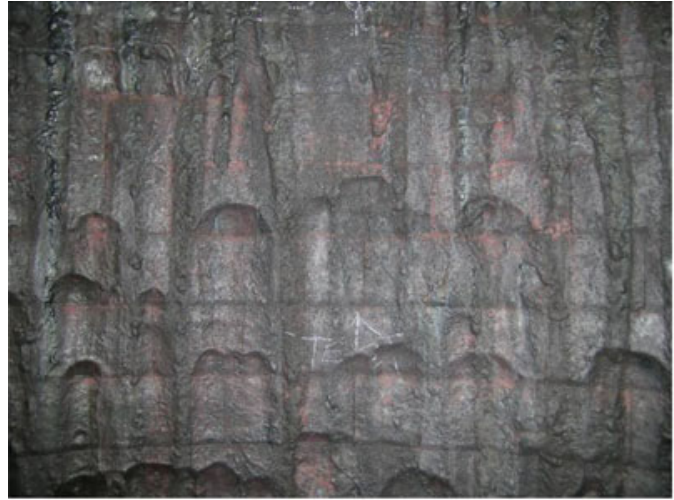

(a)

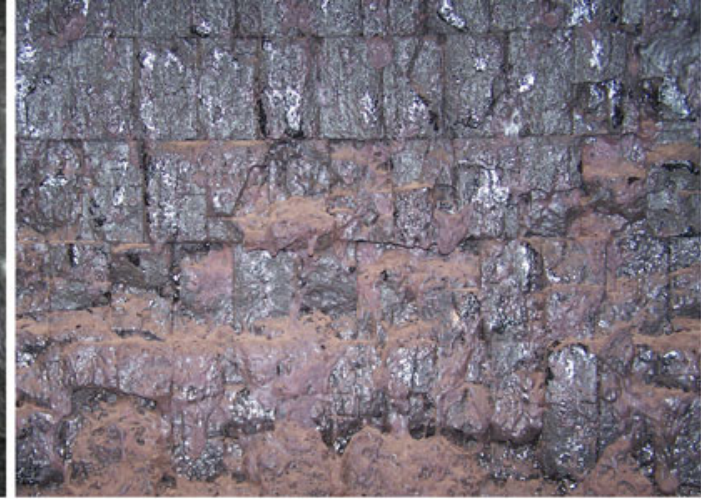

(b)

Fig. 13-Sidewall wear occurring on sidewall refractories containing approximately 90 pct chrome oxide. Figures (a) and (b) come from different gasifiers run under different operational conditions and indicate two different types of surface wear: (a) spalling occurring in large sections not limited to brick boundaries and $(b)$ spalling of individual brick. Corrosion from slag occurs at the surface of both bricks.



(a)



(b)

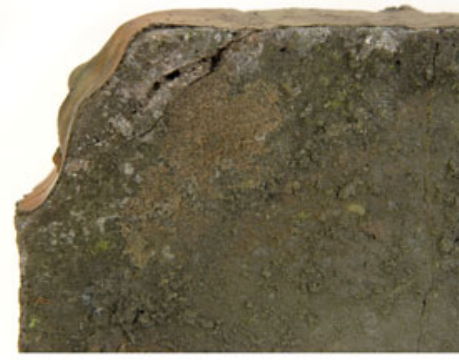

(c)

Fig. 14 -Hot face of lower cone (throat) refractory materials showing wear due to slag attack and spalling: $(a)$ lower cone area, $(b)$ thermal shock and deposits occurring because of coolant spray, and $(c)$ edge wear spalling on brick overhang between refractory layers.

temperature of gasifier operation, the number of gasifier cycles, the heating/cooling rate, the brick design, and the differences in how a material is installed. Hot-face refractory samples taken from the surface of both gasifiers had interior cracks or voids similar to Figure 7, which led to spalling.

\section{Lower Cone Failure}

The lower cone (also called the throat) connects the gasifier to the radiant syngas cooler or coolant quench chamber. The radiant syngas cooler and the quench chamber are designed to cool the syngas for processing applications downstream, as shown in the gasification flow sheet (Figure 4). The internal diameter of the lower cone is much smaller than that of the gasification chamber, which causes the molten slag exiting the gasifier to have greater mass flow per unit surface area, leading to greater erosive wear per unit time. The major cause of refractory wear in the lower cone is chemical dissolution, which occurs on the surface of the refractory (Figure 14(a)), although wear caused by other mechanisms such as spalling and thermal shock exists. Thermal shock in the lower cone layer closest to the coolant water spray (Figure 14(b)) is thought to be caused by coolant water splashing from the syngas quench chamber. Thermal shock in the sample shown in Figure 14(b) was so severe that cracking (and slag penetration into the cracks) is evident throughout the material. A white material buildup is also noted in the sample, which was analyzed and found to be high in silica. The long-term ramifications of the thermal shock and cracking are not known, but should shorten service life. Surface spalling at the corner/edge of the refractory shown in Figure 14(c) is due to slag penetration and interactions with the refractory. Exposed corners of refractory that overhang underlying refractory layers have a surface breakup, as shown in Figure 14(c), which is about $3 \mathrm{~mm}$ in thickness. It is evident that this edge spalling occurs throughout all levels of the lower cone refractory shown in Figure 14(a.) Surface corrosion, along with edge spalling and thermal shock, led to a service life in the lower cone ranging from 3 to 18 months.

\section{E. Analysis of Slag/Refractory Interactions}

As mentioned, chrome oxide can comprise up to $95 \mathrm{wt}$ pct of a hot-face refractory, and is used in gasifier refractories because it interacts with several components in the gasifier slag, forming high-melting phases (solid solutions or spinels) and a slag of higher viscosity. 


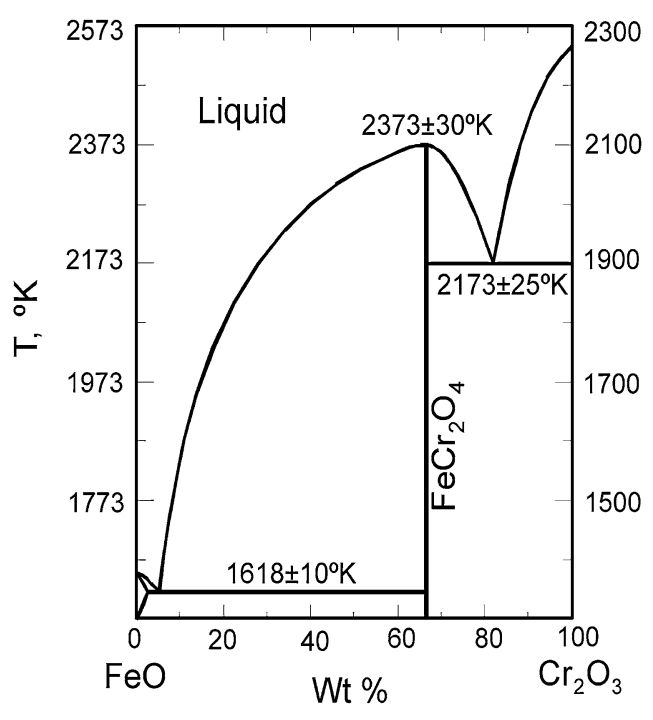

(a)

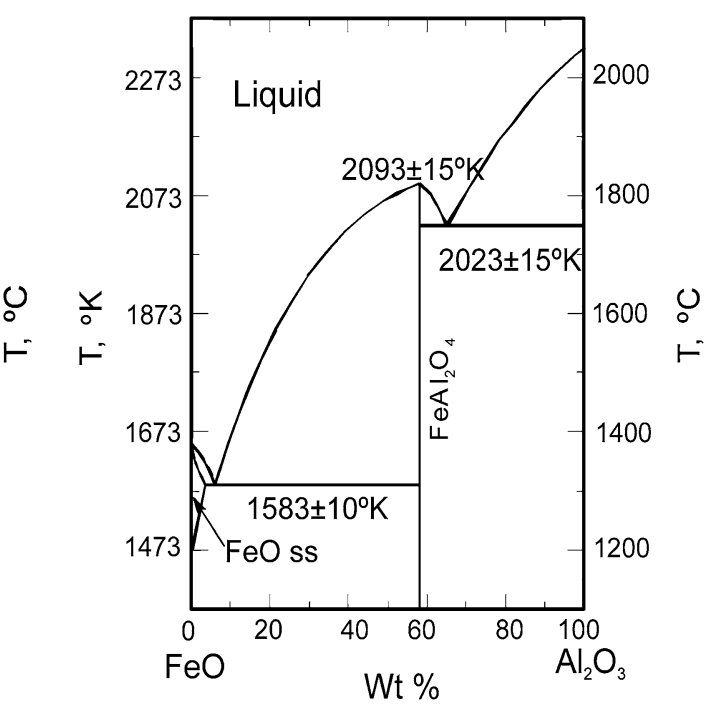

(b)

Fig. 15-Phase diagrams indicating solid and liquid phases present between $(a) \mathrm{FeO}-\mathrm{Cr}_{2} \mathrm{O}_{3}$ and $(b) \mathrm{FeO}-\mathrm{Al}_{2} \mathrm{O}_{3}$. ${ }^{[30]}$

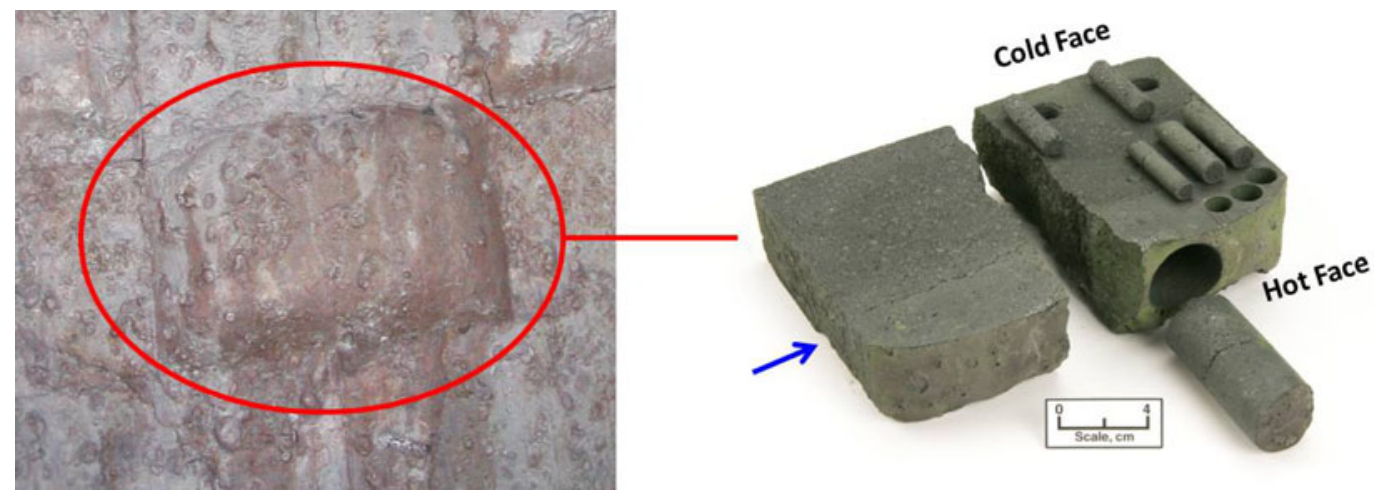

Fig. 16 - Cross section of a 90 pct chrome oxide refractory removed from a gasifier sidewall using coal as a feedstock after approximately $4000 \mathrm{~h}$ of usage between $1673 \mathrm{~K}$ and $1773 \mathrm{~K}\left(1400{ }^{\circ} \mathrm{C}\right.$ and $\left.1500^{\circ} \mathrm{C}\right)$. Note the slag penetrated area on the hot face, along with the cracking occurring at the slag penetrated/not penetrated interface, indicated by the arrow.

Alumina is often combined with chrome oxide to aid in sintering or densification and because it also forms high melting phases. Examples of how $\mathrm{Cr}_{2} \mathrm{O}_{3}$ and $\mathrm{Al}_{2} \mathrm{O}_{3}$ interact with specific slag compounds are shown in the phase diagrams of $\mathrm{FeO}-\mathrm{Cr}_{2} \mathrm{O}_{3}$ and $\mathrm{FeO}-\mathrm{Al}_{2} \mathrm{O}_{3},{ }^{[30]}$ as shown in Figures 15(a) and (b). Because of the high iron oxide content in gasifier slags (Tables I and II), the reduction or removal of $\mathrm{FeO}$ from slag leads to a higher viscosity, limiting the ability of a slag to penetrate the refractory microstructure at a given temperature.

The depth of slag penetration into a refractory with over 4000 hours of usage in a slagging gasifier (temperature generally between $1673 \mathrm{~K}$ and $1773 \mathrm{~K}\left(1400{ }^{\circ} \mathrm{C}\right.$ and $\left.1500{ }^{\circ} \mathrm{C}\right)$ ) is shown in Figure 16. A core sample taken from the spent refractory was approximately $3 \mathrm{~cm}$ in diameter and $8 \mathrm{~cm}$ in depth. The core extended from the hot face (slag penetrated area) to the cold face (no slag penetration) and was cut into discs parallel to the hot face at approximately 4-mm intervals for analysis. Slices were evaluated by SEM for microstructural changes. Ground samples taken from individual slices were also analyzed for chemistry, X-ray diffraction, and thermal expansion measurements. Analyses are presented in Table IV. Thermal expansion samples were also cored parallel to the hot face of the refractory in two areas, where the slag had infiltrated (labeled hot face), and at the cold face, where the slag had not infiltrated (labeled cold face), as shown in Figure 16.

The crystalline phase analysis of the high chrome oxide refractory $v s$ depth from the hot face to the cold face shown in Table IV indicates eskolaite $\left(\mathrm{Cr}_{2} \mathrm{O}_{3}\right)$ was the primary crystalline phase present in all layers except near the hot face (hot face to $11.4 \mathrm{~mm}$ ), which had an iron/chrome spinel phase present. In evaluating the chemistry of Table IV, it is of interest to note that iron is predominately at the hot face of the refractory, although smaller amounts are found to have penetrated the porous refractory to a depth of $38.9 \mathrm{~mm}$. The concentration of $\mathrm{CaO}$ in Table IV increases with depth from the hot face, peaking in concentration from about 25 to 
Table IV. Chemical Analysis of the Refractory Sample in Figure 16

\begin{tabular}{|c|c|c|c|c|c|c|}
\hline \multirow[b]{2}{*}{ Distance from Hot Face (mm) } & \multicolumn{5}{|c|}{ Bulk Chemistry (Wt Pct) } & \multirow[b]{2}{*}{ X-Ray Crystalline Phases } \\
\hline & $\mathrm{Cr}_{2} \mathrm{O}_{3}$ & $\mathrm{Al}_{2} \mathrm{O}_{3}$ & $\mathrm{SiO}_{2}$ & $\mathrm{CaO}$ & $\mathrm{Fe}$ & \\
\hline Hot face to 2.3 & 80.0 & 10.8 & 5.4 & 0.3 & 1.6 & $\begin{array}{l}\mathrm{P}-\mathrm{Cr}_{2} \mathrm{O}_{3} \\
\mathrm{Tr}-\mathrm{MCr}_{2} \mathrm{O}_{4}\end{array}$ \\
\hline 6.9 & 84.2 & 10.2 & 3.9 & 0.3 & 0.4 & $\begin{array}{l}\mathrm{P}-\mathrm{Cr}_{2} \mathrm{O}_{3} \\
\mathrm{Tr}-\mathrm{MCr}_{2} \mathrm{O}_{4}\end{array}$ \\
\hline 11.4 & 83.9 & 10.7 & 3.2 & 0.4 & 0.4 & $\begin{array}{l}\mathrm{P}-\mathrm{Cr}_{2} \mathrm{O}_{3} \\
\mathrm{Tr}-\mathrm{MCr}_{2} \mathrm{O}_{4}\end{array}$ \\
\hline 16.0 & 87.7 & 10.3 & 3.5 & 0.5 & 0.3 & $\mathrm{P}-\mathrm{Cr}_{2} \mathrm{O}_{3}$ \\
\hline 20.6 & 83.9 & 10.3 & 3.0 & 0.5 & 0.3 & same \\
\hline 25.1 & 83.5 & 10.7 & 3.0 & 0.6 & 0.3 & same \\
\hline 29.7 & 84.3 & 10.4 & 2.7 & 0.6 & 0.3 & same \\
\hline 34.3 & 83.5 & 10.4 & 2.8 & 0.6 & 0.4 & same \\
\hline 38.9 & 82.7 & 10.0 & 1.6 & 0.6 & 0.3 & same \\
\hline 43.3 & 83.9 & 9.3 & 2.3 & 0.5 & 0.2 & same \\
\hline 48.0 & 85.4 & 9.6 & 0.6 & 0.1 & 0.2 & same \\
\hline 52.7 & 85.7 & 10.5 & 0.9 & 0.2 & 0.2 & same \\
\hline 57.2 & 86.1 & 10.5 & 0.2 & 0.0 & 0.2 & same \\
\hline 61.7 & 86.1 & 10.6 & 0.2 & 0.0 & 0.2 & same \\
\hline 127 & 87.4 & 9.4 & 0.2 & 0.2 & 0.2 & same \\
\hline
\end{tabular}

$\mathrm{P}=$ primary phase

$\operatorname{Tr}=$ trace.

$39 \mathrm{~mm}$, than decreasing to background concentrations by $48.0 \mathrm{~mm} . \mathrm{SiO}_{2}$ is also high near the surface and decreases from the hot face to a depth of about $53 \mathrm{~mm}$, after which it is present at a background concentration. These two compounds $\left(\mathrm{CaO}\right.$ and $\left.\mathrm{SiO}_{2}\right)$ are carried as part of the slag into the porous refractory where they may react with refractory components or exist in the glassy slag phase. Since there is little thermal gradient through the hot-face refractory brick, it is thought that the viscosity of the slag increases with depth of penetration as reactions occur, limiting penetration.

Thermal expansion of samples taken from the hot face (slag-infiltrated area) and cold face (nonslag-infiltrated area) of the refractory shown in Figure 16 had the following average linear slopes between $373 \mathrm{~K}$ and $1573 \mathrm{~K}\left(100{ }^{\circ} \mathrm{C}\right.$ and $\left.1300{ }^{\circ} \mathrm{C}\right)$ when evaluated in an inert He gas:

$$
\text { Hot face: } 8.18 \times 10^{-6} \mathrm{~mm} / \mathrm{mm} / \mathrm{K}\left(\mathrm{mm} / \mathrm{mm} /{ }^{\circ} \mathrm{C}\right)
$$

Cold face: $7.68 \times 10^{-6} \mathrm{~mm} / \mathrm{mm} / \mathrm{K}\left(\mathrm{mm} / \mathrm{mm} /{ }^{\circ} \mathrm{C}\right)$

The difference between these two is 6.5 pct, which could contribute to structural spalling, which could contribute to cracking (and spalling) at the infiltrated/ noninfiltrated interface. No clear influence on expansion was noted in the oxidation/reduction behavior of these samples, which would have been caused primarily by valence changes of iron in chromia/alumina. A discussion of stresses and their possible contribution to structural spalling was previously presented. ${ }^{[29]}$ The formation of an iron/chrome spinel phase on the surface of the high chrome oxide refractory is thought, however, to contribute to chemical (micro)-spalling and refractory wear at the refractory hot face/slag interface due to volume changes associated with the formation of the spinel phase. Chemical (micro)-spalling will be discussed later.

Evidence of the surface reaction of iron is also shown in a hot-face to cold-face cross section of the slag/ refractory interface analyzed by SEM (Figure 17), along with phases identified by EDX chemical analysis at specific points in the slag and in the refractory (Table V). This refractory sample came from a gasifier using coal as a feedstock in an oxygen partial pressure of about $10^{-8}$ atm at temperatures from $1673 \mathrm{~K}$ to $1773 \mathrm{~K}$

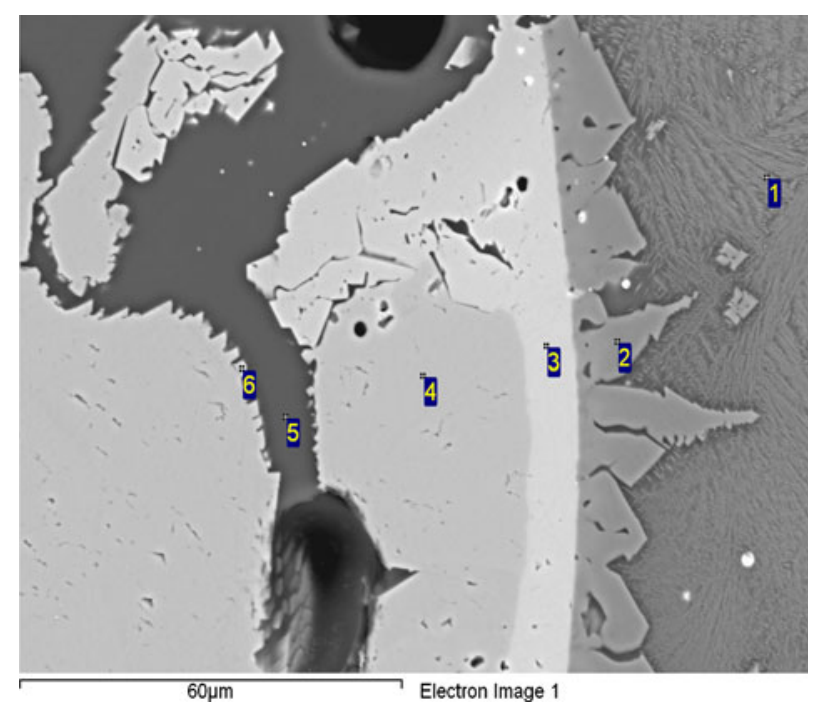

Fig. 17-SEM backscatter micrograph of a high chrome oxide refractory slag/refractory interface exposed to a coal slag between $1673 \mathrm{~K}$ and $1773 \mathrm{~K}\left(1400{ }^{\circ} \mathrm{C}\right.$ and $\left.1500{ }^{\circ} \mathrm{C}\right)$ for approximately $2000 \mathrm{~h}$ of exposure at an oxygen partial pressure of $10^{-8}$. Markings 1 through 6 indicate points where EDX elemental analyses were taken (chemistry is given in Table V). 
Table V. EDX Chemistry of Points 1 through 6 in Figure 17; Chemistries Are for a High Chrome Oxide Refractory Exposed to a Coal Slag in a Gasifier at an Oxygen Partial Pressure of About $10^{-8}$ from $1673 \mathrm{~K}$ to $1773 \mathrm{~K}\left(1400{ }^{\circ} \mathrm{C}\right.$ to $1500{ }^{\circ} \mathrm{C}$ ) for About 2000 Hours

\begin{tabular}{lrrrrrr}
\hline & \multicolumn{5}{c}{ Point Chemistry (Wt Pct) } \\
\cline { 2 - 7 } Element & \multicolumn{1}{c}{1} & \multicolumn{1}{c}{2} & \multicolumn{1}{c}{3} & \multicolumn{1}{c}{4} & \multicolumn{1}{c}{5} & 6 \\
\hline $\mathrm{Al}$ & 6.9 & 27.3 & 1.7 & 2.8 & 7.5 & 5.7 \\
$\mathrm{Si}$ & 23.9 & 0.2 & 0.1 & 0.1 & 40.2 & 3.8 \\
$\mathrm{Fe}$ & 20.8 & 31.7 & 23.6 & 0.2 & 1.5 & 0.5 \\
$\mathrm{Ca}$ & 1.5 & - & - & - & 0.5 & - \\
$\mathrm{Cr}$ & 0.1 & 1.5 & 42.7 & 62.1 & 1.5 & 53.0 \\
\hline
\end{tabular}

$\left(1400{ }^{\circ} \mathrm{C}\right.$ to $1500{ }^{\circ} \mathrm{C}$ ) for about 2000 hours. The SEM backscatter image of Figure 17 indicates that distinct zones exist in the refractory where point EDX chemistry was determined: point 1 -slag near the refractory face, point 2-phase buildup along the refractory surface, point 3-diffusion layer that occurs parallel to the refractory hot face, point 4 -interior refractory grain, point 5-pore slag, and point 6-refractory/slag interface phase in a pore. Interpretation of each point in Figure 17 using the chemistries in Table V is as follows.

Point 1 -slag near the refractory surface. The slag area near the surface of the refractory had a fine dendritic-type structure that occurred on gasifier cooldown. Phases present could include hercynite $\left(\mathrm{FeAl}_{2} \mathrm{O}_{4}\right)$, fayalite $\left(\mathrm{Fe}_{2} \mathrm{SiO}_{4}\right)$, or other compounds. Specific phases depend on the ash composition of the coal, dissolution from the refractory, the cooling rate of the gasifier, and the gasifier atmosphere during cooldown.

Point 2-phase buildup along the refractory surface. The phase grew from the surface of the refractory and was determined to have chemistry near that of hercynite $\left(\mathrm{FeAl}_{2} \mathrm{O}_{4}\right)$. Planar $\mathrm{FeAl}_{2} \mathrm{O}_{4}$ growth appeared to have occurred during service, with dendritic growth probably occurring during cooldown. The $\mathrm{FeAl}_{2} \mathrm{O}_{4}$ phase appeared to be stable during gasification at the service temperature. It is not clear from where the aluminum in this phase originated (slag, refractory, or both), but iron originated from the slag.

Point 3-diffusion layer that occurs parallel to the refractory hot face. This layer was very uniform along the slag/refractory grain surface. It is speculated that aluminum migrated from the refractory surface, while iron originated from the slag. This layer, along with the $\mathrm{FeAl}_{2} \mathrm{O}_{4}$, appeared to form a barrier coating on the surface of the refractory grain, impacting the diffusion of $\mathrm{Fe}$ into, or $\mathrm{Al}$ out of, the refractory microstructure. At the slag/refractory interface, the $\mathrm{FeCr}_{2} \mathrm{O}_{4}$ layer had $\mathrm{FeAl}_{2} \mathrm{O}_{4}$ growth on its surface, while in the pore area where the slag chemistry had changed ( $\mathrm{Fe}$ depleted slag chemistry), no $\mathrm{FeAl}_{2} \mathrm{O}_{4}$ growth occurred.

Point 4-interior refractory grain. The chemistry of the grain contained $\mathrm{Al}$ and $\mathrm{Cr}$, probably in a ratio similar to the starting refractory grain chemistry. It is a solid solution, with no fixed chemistry.
Point 5-pore slag. The chemistry of the slag did not indicate crystallization growth as surface slag did. Slag chemistry had significantly lower quantities of Fe and a higher amount of Si (comparison of points 1 surface slag $v s$ point 5 pore slag). Also note that the static slag in the pore had slightly higher quantities of $\mathrm{Cr} v s$ surface slag.

Point 6-refractory/slag interface phase in a pore. The EDX chemistry of point 6 vs the internal refractory grain (point 4) indicates higher amounts of $\mathrm{Si}$ and $\mathrm{Al}$, slightly higher $\mathrm{Fe}$, and a pronounced decrease in $\mathrm{Cr}$. The slight buildup in Si may be explained by thermodynamic modeling, which is discussed in Section II-F.

The microstructure illustrated in Figure 17 and the chemistry of points 1 through 6 (listed in Table V) evolved through a series of complex refractory/slag thermodynamic and kinetic reactions. Iron-oxide in the coal slag (point 1) reacts with chromium contained in the chrome-alumina solid solution refractory grain (point 4) to form a stoichiometric iron-chrome spinel (point 3) containing approximately $24 \mathrm{wt}$ pct Fe. As mentioned, the spinel layer has a chemical composition matching a fixed chemistry of $\mathrm{FeCr}_{2} \mathrm{O}_{4}$. Once formed, the $\mathrm{FeCr}_{2} \mathrm{O}_{4}$ spinel layer becomes a barrier that must be overcome by iron diffusing inward from the slag and alumina diffusing outward from the chrome-alumina grain. Note that the chemistry at point 3 indicated a pronounced reduction in the amount of $\mathrm{Al}$ present from that amount in the starting refractory grain (point 4). At the surface, with a continual supply of iron oxide, a layer of iron-aluminum spinel forms (point 2) on the slag side of the iron-chromium spinel. The chemistry of this point closely matches that for $\mathrm{FeAl}_{2} \mathrm{O}_{4}$. In both the $\mathrm{FeCr}_{2} \mathrm{O}_{4}$ and the $\mathrm{FeAl}_{2} \mathrm{O}_{4}$ layers, there appears to be some substitution of $\mathrm{Al}, \mathrm{Cr}$, and $\mathrm{Fe}$ in the structures. With the formation of this double layer, protective surface coating on the refractory surface, diffusion appears to limit the iron-chromium layer to around 5 to $10 \mu \mathrm{m}$. An unexplained layer slightly higher in $\mathrm{SiO}_{2}$ (point 6) is noted in the pore interior. The reason for this slight silica enrichment can be explained by thermodynamic modeling that will follow.

Without the protective $\mathrm{FeAl}_{2} \mathrm{O}_{4}$ and $\mathrm{FeCr}_{2} \mathrm{O}_{4}$ layers on the surface to inhibit diffusion, the iron-chromium spinel phase continues to grow as long as iron from the slag is available. When the iron-chromium spinel crystals reach a certain size (thickness), internal stress related to the associated volume change (from the chromia/alumina solid solution grain to the $\mathrm{FeCr}_{2} \mathrm{O}_{4}$ spinel structure) causes microspalling (chemical spalling) at the surface. This seems to occur once the iron-chrome spinel layer exceeds 10 to $20 \mu \mathrm{m}$ in thickness. The $\mathrm{FeCr}_{2} \mathrm{O}_{4}$ structure seems to "seal" the surface of the refractory from direct high iron slag contact. Ironchromium spinel crystal formation below the refractory/ slag interface is somewhat self-limiting because of the much lower Fe content of the slag (point 5). Once a static slag pool in a pore is depleted of iron, the slag becomes silica rich, further complicating the formation of either $\mathrm{Fe} / \mathrm{Al}$ or $\mathrm{Fe} / \mathrm{Cr}$ spinel phases. Some limited 
dissolution of chrome into the reactive slag also occurs, but never exceeds approximately $0.1 \mathrm{wt}$ pct immediately adjacent to the refractory surface. While this amount is small, considering the volume of carbon feedstock slag (at some gasifier sites, this can exceed 100 metric tons/ day), it could lead to measurable material loss.

It is important to note that Figure 17 and the accompanying discussion are for a gasifier using coal as the carbon source. When petcoke or biomass carbon feedstock is used in place of or in addition to coal, other reactions will occur depending on compositional differences.

\section{F. Thermodynamic Analysis of Slag/Refractory Interactions}

Thermodynamics can be used to predict stable phases existing in a gasifier environment; however, it must be remembered that thermodynamics do not predict reaction kinetics, and that thermodynamic calculations may be limited by incomplete databases (such as with vanadium compounds contained in petcoke slags) or by complexities when calculating multicomponent phase equilibrium associated with gasifiers. In the two examples that will be discussed related to Figure 17 (for a coal slag), FACTSAGE** software was used to predict

**FACTSAGE is a trademark of Thermfact/CRCT (Montreal, Canada) and GTT Technologies (Aachen, Germany).

possible phases present in the point chemistries given in Table V, with the results plotted in Figures 18 and 19. The gasification conditions used to predict the thermodynamic phases present were $1673 \mathrm{~K}\left(1400^{\circ} \mathrm{C}\right)$ and an oxygen partial pressure of $10^{-8}$. Interactions between two phases were determined: between points 1 and 4 (slag and the refractory grain), and between points 1 and 3 (slag and the iron chromate compound on the surface of the refractory). Results were calculated on the basis of weight ratios of the mixture of points 1 and 4 (wt pt $4 /($ wt pt $4+$ wt pt 1)), as shown in Figure 18, and the weight ratio of points 1 and 3 (wt pt $3 /(w t$ pt $3+$ wt pt 1)), as shown in Figure 19. The chemistry weight ratio goes from 100 pct slag phase (representing slag chemistry of point 1 in Figure 17) on the left $x$-axis of Figure 18 (the sample is all slag, no refractory grain within the slag) to 100 pct refractory grain (the mixture is all refractory grain). A similar behavior exists in Figure 19, where the $x$-axis goes from 100 pct slag phase on the left to 100 pct point 3 spinel phase chemistry on the right. In between either extreme are combinations of slag and solid and refractory phases.

The thermodynamic phases predicted in Figure 18 for different combinations of points 1 and 4 indicate that as the slag begins to interact with chromia/alumina refractory grain (weight ratio 0 in Figure 18), a fixed composition spinel $\left(\mathrm{FeCr}_{2} \mathrm{O}_{4}\right)$ is predicted to form, followed by a solid solution that is a mixture of varying $\mathrm{Cr}$ and $\mathrm{Al}$. The $\mathrm{Fe} / \mathrm{Cr}$ phase noted to form in Figure 17 (at point 3) when the slag interacts with the surface of the refractory grain has a $\mathrm{Fe} / \mathrm{Cr}$ weight ratio of 0.553 ,

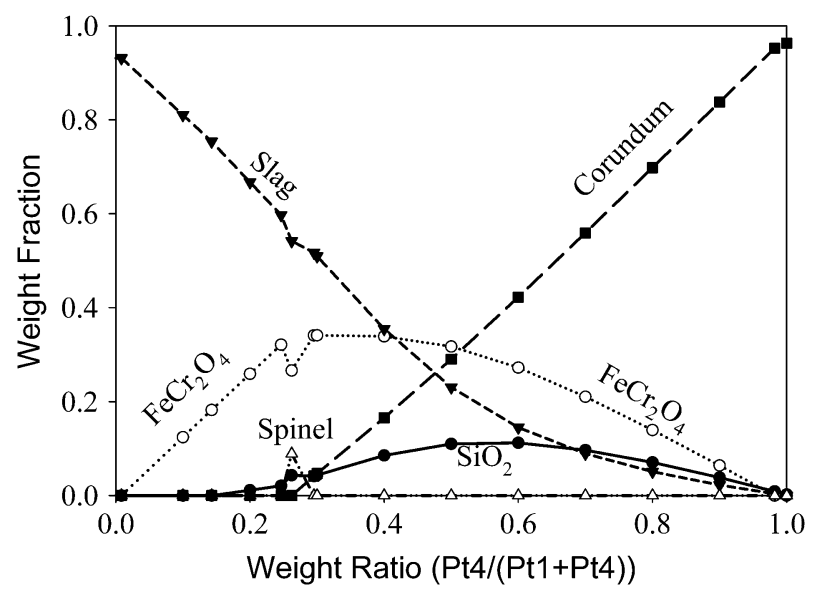

Fig. 18-Thermodynamic prediction of stable weight phases for different weight ratio mixtures of coal slag chemistry at point 1 and refractory grain chemistry at point 4 (wt pt $4 /$ wt pt $4+$ wt pt 1 ) at $1673 \mathrm{~K}\left(1400{ }^{\circ} \mathrm{C}\right)$ and $10^{-8}$ oxygen partial pressure, based on SEMEDX compositions listed in Fig. 17. Point 4 is a refractory grain of solid solution chemistry containing $\mathrm{Cr}_{2} \mathrm{O}_{3} / \mathrm{Al}_{2} \mathrm{O}_{3}$. Note that this diagram was produced using FACTSAGE. Chemistry is based on points shown in Fig. 17, the chemical analysis of which are listed in Table V.

while the compound predicted by thermodynamics $\left(\mathrm{FeCr}_{2} \mathrm{O}_{4}\right)$ has a $\mathrm{Fe} / \mathrm{Cr}$ weight ratio of 0.537 . This suggests that the phase formed by slag and refractory interactions on the surface of the refractory grain in Figure 19 is $\mathrm{FeCr}_{2} \mathrm{O}_{4}$. It is of interest to note that in Figure $18, \mathrm{SiO}_{2}$ was predicted to form as a stable phase and that elevated levels of $\mathrm{Si}$ were found to exist at the surface of interior slag/refractory grains in contact with depleted slag (point 6 in Figure 17).

Once slag and chromia/alumina refractory grain interact to form $\mathrm{FeCr}_{2} \mathrm{O}_{4}$ spinel on the refractory surface, the spinel structure exists as a stable boundary layer, slowing further interactions between the refractory chromia/alumina grain and slag. This is shown in Figure 17, where contact between surface slag and the chromia/alumina solid solution grain does not occur. In Figure 17, note that slag (point 1) is in contact with a $\mathrm{Fe} / \mathrm{Al}$ phase (point 2), not with the $\mathrm{Fe} / \mathrm{Cr}$ spinel structure (point 3). It could not be determined from the SEM micrographs whether the Fe/Al phase formed on cooling or if it was formed at elevated temperatures during use; however, it was speculated that the laminar growth pattern exhibited at the original refractory-slag interface occurred at high temperature, while the dendritic growth extended into the slag may have occurred later during cooling. How this structure forms during gasification will be clarified to some extent in the following thermodynamic section. When plotting the thermodynamic interactions between point $3\left(\mathrm{FeCr}_{2} \mathrm{O}_{4}\right)$ and point 1 (slag) in Figure 19, it is noted that a stable $\mathrm{FeCr}_{2} \mathrm{O}_{4}$ phase can exist with slag and that increasing slag additions result in the formation of a stable spinel structure. In evaluating the thermodynamic data, this stable spinel phase is made predominately of $\mathrm{FeAl}_{2} \mathrm{O}_{4}$, although other spinel phases are present, and the ratio of the phases varies depending on the weight ratio of points 1 and 3 . The results indicate that $\mathrm{FeAl}_{2} \mathrm{O}_{4}$ can be 


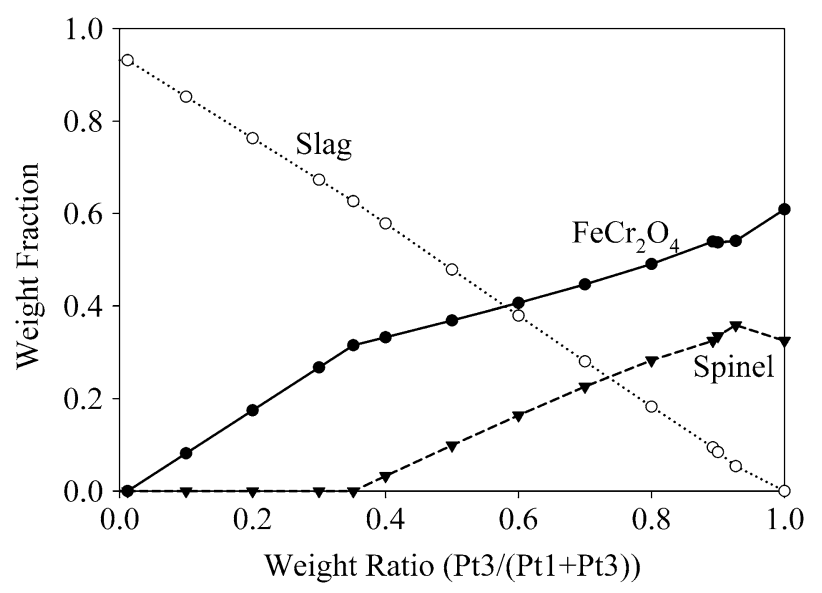

Fig. 19-Thermodynamic prediction of stable weight phases for different weight ratio mixtures of coal slag chemistry at point 1 and surface material chemistry at point 3 (wt pt $3 /$ wt pt $3+$ wt pt 1 ), based on SEM-EDX compositions listed in Fig. 8. Point 3 area has a fixed chemistry indicating a $\mathrm{FeAl}_{2} \mathrm{O}_{4}$ spinel composition. Note that this diagram was produced using FACTSAGE. Chemistry is based on points shown in Fig. 17, the chemcial analysis of which are listed in Table V.

a stable phase that forms between the slag and $\mathrm{FeCr}_{2} \mathrm{O}_{4}$, although with increasing slag concentration, it will dissolve into the slag.

Thermodynamics can also be used to predict the impact of gasification conditions (temperature and oxygen partial pressure) on refractory dissolution, something that is difficult to monitor during gasification. FACTSAGE was used to model $100 \mathrm{~g}$ mixtures of slag (point 1) and refractory grain (point 4 ) from Table $\mathrm{V}$ (points indicated in the refractory/slag interaction in Figure 17) between $1673 \mathrm{~K}$ and $1873 \mathrm{~K}\left(1400{ }^{\circ} \mathrm{C}\right.$ and $1600{ }^{\circ} \mathrm{C}$ ) and oxygen partial pressures from $10^{\circ}$ to $10^{-12} \mathrm{~atm}$. The formation of $\mathrm{CrO}$ and $\mathrm{Cr}_{2} \mathrm{O}_{3}$ soluble in the slag was predicted, and the combined total is shown in Figure 20. Decreasing the oxygen partial pressure or increasing the temperature was noted to increase the chemical dissolution of chrome in the slag, especially above $1773 \mathrm{~K}\left(1500{ }^{\circ} \mathrm{C}\right)$ or at oxygen partial pressures below $10^{-6} \mathrm{~atm}$. The increase in chrome solubility in the slag with temperature or a decrease in oxygen partial pressure accounts for the slight amount of chrome indicated in the surface slag (point 1) or pore slag (point 5).

\section{SUMMARY AND CONCLUSIONS}

Because of their high efficiency, ability to capture $\mathrm{CO}_{2}$ for sequestration or reuse in other applications, and potential for carbon feedstock fuel flexibility, air-cooled slagging gasifiers are used by industry to produce $\mathrm{CO}$ and $\mathrm{H}_{2}$ for power production, are used as a feedstock material for the chemical industry, are considered a possible source of $\mathrm{H}_{2}$ in a hydrogen-based economy, and hold potential for use in the advanced fossil fuel power systems of the future. Gasifiers are used commercially to react a carbon feedstock, water, and oxygen (shortagereducing conditions) at temperatures between $1598 \mathrm{~K}$

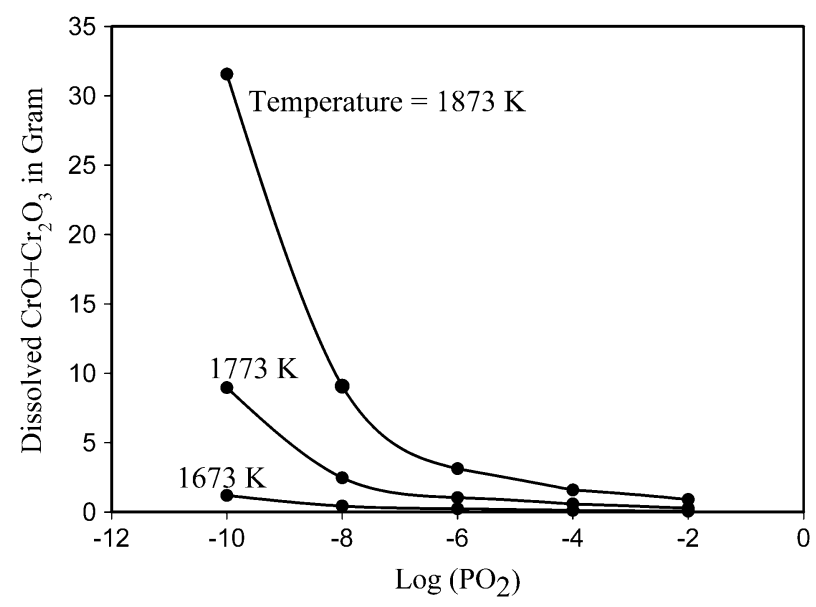

Fig. 20-Thermodynamic prediction of stable $\mathrm{CrO}$ and $\mathrm{Cr}_{2} \mathrm{O}_{3}$ in gasifier slag using slag chemistry of point 1 and refractory grain chemistry of point 4 in Table $\mathrm{V}$. Note that this diagram was produced using FACTSAGE.

and $1848 \mathrm{~K}\left(1325^{\circ} \mathrm{C}\right.$ and $\left.1575^{\circ} \mathrm{C}\right)$ and at pressures between 2.07 and $6.90 \mathrm{MPa}$. Impurities in the carbon feedstock liquefy at the elevated gasification temperatures, interacting with the high chrome oxide liners that protect the gasifier steel shell and lead to refractory failure. Refractory liners may be exposed to 100 or more tons of molten slag that is high in $\mathrm{Si}, \mathrm{Fe}, \mathrm{Ca}$, and $\mathrm{Al}$. Failure of the refractory lining can occur between 3 and 30 months, a life that is dependent on variables such as the ash chemistry and quantity, the operating temperature of the gasifier, gasifier maintenance, and the frequency of gasifier cycling. Gasifier liners contain between 60 and 95 pct chrome oxide, with the balance of the composition being either alumina or alumina and zirconia. The use of gasification as a process is limited because it does not achieve the on-line availability or reliability necessary for economical operation. Refractories were identified as the leading research need of the gasification process. Refractory lining failure is caused primarily by chemical dissolution of the chrome oxide at the slag/refractory interface, chemical spalling at the slag/refractory interface, and structural spalling caused by molten slag penetration into the refractory. Using postmortem analysis and thermodynamic modeling, slag interactions at the refractory surface and interior were determined. Chrome oxide was determined to have low solubility in the slag, while slag $\mathrm{FeO}$ was determined to interact with the refractory $\mathrm{Cr}_{2} \mathrm{O}_{3}$ to form $\mathrm{FeCr}_{2} \mathrm{O}_{4}$ as a layer on the grain surface, which appeared to fracture when it became thick (over $20 \mu \mathrm{m}$ ). A layer of $\mathrm{FeAl}_{2} \mathrm{O}_{4}$ was determined to form on the surface of the $\mathrm{FeCr}_{2} \mathrm{O}_{4}$. Both layers would act to impact refractory wear and corrosion by acting as a diffusion boundary. The presence of $\mathrm{FeAl}_{2} \mathrm{O}_{4}$ and $\mathrm{FeCr}_{2} \mathrm{O}_{4}$ observed through postmortem analysis and the presence of a high silica area inside pores, along with a depletion of $\mathrm{Cr}_{2} \mathrm{O}_{3}$ in these areas, were explained by the use of thermodynamic modeling. The mechanisms of wear in high chrome oxide gasifier refractories are complex; however, through an understanding of them, improved refractory liner materials can be developed. 


\section{REFERENCES}

1. Information available from the UHDE website: www.uhde.biz, The Shell Gasification Process, Aug. 10, 2005.

2. General information from the website for Shell Gas and Power; internet website: www.shell.com, Aug. 1, 2005.

3. N. Richter: Introduction to Gasification (ChevronTexaco), internet website: www.gasification.org/Docs/02Richter.pdf, Aug. 2, 2005.

4. W.A. Selvig and F.H. Gibson: USBM Bull. Pub., 1956, vol. 567, pp. 1-33.

5. S.V. Vassilev, C. Braekman-Danheux, R. Moliner, I. Suelves, M.J. Lázaro, and T. Thiemann: Fuel, 2002, vol. 81, pp. 1281-96.

6. R.E. Conn: Fuel Process. Technol., 1995, vol. 44, pp. 95-103.

7. R.W. Bryers: Fuel Process. Technol., 1995, vol. 44, pp. 121-41.

8. "Gasification Markets and Technologies-Present and Future-An Industry Perspective," US DOE/FE Report No. 0447, US DOE, Washington, DC, July 2002, pp. 1-53.

9. G. Stiegel and S. Clayton: DOE Gasification Industry $R \& D$ Survey: A Perspective of Long Term Market Trends and R\&D Needs, Proc. Gasification Technologies 2001 Annual Meeting, San Francisco, CA, 2001.

10. W.T. Bakker, S. Greenberg, M. Trondt, and U. Gerhardus: Am. Ceram. Soc. Bull., 1984, vol. 63 (7), pp. 870-76.

11. J.A. Bonar, C.R. Kennedy, and R.B. Swaroop: Am. Ceram. Soc. Bull., 1980, vol. 59 (4), pp. 473-78

12. G. Sorell, M.J. Humphries, E. Bullock, and M. Van de Voorde: Int. Met. Rev., 1986, vol. 31 (5), pp. 216-42.

13. W.A. Taber: Refract. Applic. News, 2003, vol. 8 (4), pp. 18-22.

14. R.C. Johnson and M.S. Crowley: Proc. Unified International Technical Conf. on Refractories, UNITECR '05, Orlando, FL, Nov. 2005, J.D. Smith, ed., American Ceramic Society, Cleveland, OH, pp. 1-4.

15. N.S. Raymon and L.Y. Saddler III: "Refractory Linings Materials for Coal Gasifiers - A Literature Review of Reactions Involving High-Temperature Gas and Alkali Metal Vapors," USBM Information Circular 8721, U.S. Bureau of Mines, Washington, DC, 1976, pp. 1-22.

16. S. Greenberg and R.B. Poeppel: "The Corrosion of Ceramic Refractories Exposed to a Synthetic Coal Slag by Means of the
Rotating-Drum Technique," Research Report ANL/FE-85-9, research sponsored by USDOE/FE, pp. 1-15.

17. S. Greenberg and R.B. Poeppel: "The Corrosion of Ceramic Refractories Exposed to Synthetic Coal Slags by Means of the Rotation-Cylinder Technique: Final Report," Research Report No. ANL/FE - 85-15, research sponsored by USDOE/FE and EPRI, Apr. 1986, pp. 1-66.

18. C.R. Kennedy and R.B. Poeppel: Interceramics, 1978, vol. 27 (3), pp. 221-26.

19. C.R. Kennedy, R. Swaroop, D. J. Jones, R. J. Fousek, R. B. Poeppel, and D. Stahl: "Evaluation of Ceramic Refractories for Slagging Gasifiers: Summary of Progress to Date," ANL Report No. 78-61, research sponsored by USDOE, Sept. 1978.

20. A.P. Starzacher: Radex-Rundschau, 1988, vol. 1, pp. 491-501.

21. R.E. Dial: Am. Ceram. Soc. Bull., 1975, vol. 54 (7), pp. 640-43.

22. M.S. Crowley: Am. Ceram. Soc. Bull., 1975, vol. 54 (12), pp. 1072-74.

23. J. Nakano, J. Bennett, K.S. Kwong, S. Seetharaman, and T. Moss: Proc. VIII Int. Conf. on Molten Slags, Fluxes, and Salts, Santiago, Chile, Jan. 18-21, Gecamin Ltd., Santiago, Chile, 2009, pp. 1-10.

24. Z. Guo: Internet publication of the Am. Ceram. Soc. Bull., June 2004, pp. 9101-08, www.cerramicbulletin.org.

25. J.P. Bennett, K.S. Kwong, and J. Nakano: Proc. COM 2010, Vancouver, BC, Canada, Oct. 3-8, 2010, Advances in Refractories V-The Michel Rigaud Symp., G. Opera and J.G. Hemrick, eds., The Canadian Institute of Mining, Metallurgy and Petroleum, West Westmount, Québec, Canada, 2010, pp. 279-92.

26. W.T. Bakker: Key Engineering Materials, Trans Tech Publications, Aedermannsdorf, Switzerland, 1993, vol. 88, pp. 41-70.

27. W.L. Headrick, Jr., M. Karakus, and X. Laing: "Refractory for Black Liquor Gasifiers," Topical Report Task 1.4, DOE Award No. DE-FC26-02NT41491, Oct. 2005.

28. J.R. Keiser, J.G. Hemrick, J.P. Gorog, and R. Leary: "Improved Materials for High-Temperature Black Liquor Gasification," Technical Report No. ORNL/TM-2006/71, June 2006.

29. R.E. Williford, K.I. Johnson, and S.K. Sundaram: Ceram. Int., 2008, vol. 34, pp. 2085-89.

30. ACerS-NIST Phase Equilibria Diagrams CD-ROM Database Version 3.1, American Ceramic Society, Cleveland, OH, 2010. 